\title{
STRATYFIKACJA SPOŁECZNA LUDNOŚCI ZACHODNIOPODOLSKIEJ GRUPY KULTURY WCZESNOSCYTYJSKIEJ
}

\author{
SOCIAL STRATIFICATION OF THE POPULATION \\ OF THE WESTERN-PODOLIAN GROUP OF THE EARLY SCYTHIAN CULTURE
}

The paper raises the question of the reconstruction of the social structure of the Western-Podolian group of the Early Scythian culture (ESC), based on materials from burials. As a result of the analysis of the most important elements of funeral rites of the population of this group, as well as based on ancient writers (The H istories by Herodotus), it was established that the size and the complexity of construction of a burial and a mound covering the burial, as well as the diversification of quantity and quality of grave goods, seem to be of the most value for this issue. The classification of 100 burial complexes carried out on the basis of these features, with the use of statistical inference methods (cluster and correspondence analyses), has led to the differentiation of six classes of graves, which can be combined with different social classes. The higher (military leaders and chieftains) and the lower aristocracy, the ordinary population with the distinguishing class of warriors and the poorest population are numbered to these classes. Apart from these classes, connected with the free, fully-fledged population, a group of the partly dependent population with limited rights has been also differentiated.

KEY WORDS: burials, social stratification, Western-Podolian group, Early Scythian Culture, Early Iron Age, Western Ukraine

\section{ZAGADNIENIA WSTĘPNE}

Celem niniejszej publikacji jest przedstawienie jednego z możliwych sposobów badania i interpretacji zagadnienia znaczenia obrządku pogrzebowego dla rekonstrukcji stratyfikacji społecznej zachodniopodolskiej grupy kultury wczesnoscytyjskiej ${ }^{1}$ (dalej RSK z ros. ranneskifskaâ kul'tura - por. Medvedskaâ 1992, 86). W ujęciu wielu ba-

1 Projekt został sfinansowany ze środków Narodowego Centrum Nauki przyznanych na podstawie decyzji numer DEC-2013/09/N/HS3/02839. daczy, a w szczególności tych związanych z nurtem archeologii procesualnej, obrządek pogrzebowy jawi się bowiem jako jedno z podstawowych źródeł dla kreowania wizji szeroko rozumianej struktury społecznej w pradziejach (przegląd najważniejszych teorii i literatury - Brown 1995; Härke 1997; 2000; Lewartowski 2001; Ciesielska 2002; Chapman 2003; Błaszczyk 2013).

Jak dotąd nie podjęto szczegółowych studiów w zakresie struktury społecznej ludności zachodniopodolskiej grupy RSK. Problematyka ta była 
podejmowana jedynie w ogólnikowy sposób, najczęściej poprzez odnotowanie obecności na cmentarzyskach użytkowanych przez ludność tego ugrupowania kulturowego wyróżniających się zespołów grobowych określanych jako miejsca pochówku przedstawicieli wyższych warstw społecznych - elit (Smirnova 1979, 41; Gucal et al. 2011a, 106; Gucal 2012, 154). O wysokiej pozycji (randze) zmarłego świadczyć mają wielkość nasypu kurhanowego i komory grobowej, jej złożoność oraz bogactwo inwentarza, z pierwszoplanową rolą przedmiotów uzbrojenia (Smirnova 1979, 41; Gawlik 2010, 162; Gucal et al. 2011a, 106; Gucal 2012, 154). Na obecność $\mathrm{w}$ badanym społeczeństwie wyższych sfer w typie wojskowych elit wskazywali także badacze zajmujący się różnymi aspektami związanymi z funkcjonowaniem tego ugrupowania kulturowego (np. Sulimirski 1936, 29; Kubczak 1978, 117; Gawlik 2009, 608; 2010, 160-162; Bandrìvs'kij 2010b, 97; 2014, 338, 339, 367, 538; Chochorowski 2015, 21, 25, 43). Szczególne często kwestia ta poruszana była przy okazji badań nad genezą zachodniopodolskiej grupy RSK. Przyjęło się bowiem uważać, że ugrupowanie to powstało w wyniku napływu w VII w. p.n.e. na tereny środkowego i górnego dorzecza Dniestru zajętych przez ludność związaną z kulturami wywodzącymi się jeszcze z epoki brązu (kultura czarnoleska i holihradzka) grup nomadów (głównie mężczyzn wojowników - Smirnova 1998, 460) o „scytyjskim” modelu kulturowym
(Chochorowski 2015, 21, 25). Szczególnie mocno podkreśla się rolę przybyszów jako dominującego społecznie superstratu (Sulimirski 1936, 29; Smirnova 1998, 460; Gawlik 2010, 156-157, 160-162; Chochorowski 2015, 25). Jak pisze Tadeusz Sulimirski $(1936,29)$, jego przedstawiciele sprawowali władzę nad miejscową „rolniczą ludnością od dawna w kraju zamieszkałą". Zdaniem części badaczy stosowany przez reprezentantów wyższych warstw obrządek pogrzebowy z wyraźnym dążeniem do zamanifestowania, poprzez wielkość i formę grobu oraz złożone w nim wyposażenie grobowe, wysokiej pozycji (rangi) społecznej zmarłego świadczy o kultywowaniu przez nich koczowniczych (,scytyjskich") tradycji, z podkreśleniem typowej dla tego środowiska hierarchii społecznej (Gawlik 2009, 460; 2010, 160, 162).

Problem zróżnicowania społecznego ludności zachodniopodolskiej grupy RSK został podjęty również przez autora niniejszej publikacji. W pracy poświęconej broni i wojskowości tego ugrupowania kulturowego na podstawie analizy rozmiarów nasypu, wielkości i złożoności konstrukcji grobowych oraz składu inwentarza wydzielono trzy główne grup społeczne: elity (z podziałem na arystokrację wyższego rzędu w typie wojskowych naczelników oraz arystokrację niższego rzędu) - warstwę średnią - warstwy niższe (Burghardt 2015, 160-162). Należy jednak zaznaczyć, że zaproponowana klasyfikacja dotyczy wyłącznie pochówków z bronią.

\section{WYBÓR CECH OBRZĄDKU POGRZEBOWEGO DO ANALIZ I KRYTYKA ŹRÓDEŁ}

Podstawowe pytanie, na które należy odpowiedzieć przy badaniu struktury społecznej ludności zachodniopodolskiej grupy RSK, dotyczy kwestii, które $\mathrm{z}$ aspektów stosowanego przez nią obrządku pogrzebowego mogą być przydatne do analiz społecznych. To właśnie dobór odpowiedniej metody badawczej i cech pochówków ma istotny wpływ na tworzony przez archeologa w oparciu o materiały sepulkralne obraz struktury społecznej badanej ludności (por. Ciesielska 2009, 45).

W archeologii zajmującej się strukturami społecznymi do najczęściej analizowanych aspektów obrzędowości pogrzebowej należy wyposażenie grobowe (jego zróżnicowanie ilościowe i jakościowe) oraz sposób pochówku i jego lokalizacja (forma grobu). W przypadku wyposażenia grobowego szczególnie często podkreślana jest jego rola jako czynnika „wskazującego” na rozwarstwienie majątkowe i społeczne panujące w danym społeczeństwie (Gryzińska-Sawicka 2014, 51). Szczególny nacisk przy badaniach nad strukturą społeczną w oparciu o analizę wyposażenia grobowego kładziony jest na rozpoznanie symboli bogactwa i pozycji społecznej (prestiżu) - więcej da się bowiem wywnioskować na podstawie przedmiotów wartościowych, których występowanie jest ograniczone, niż spotykanych masowo przedmiotów powszechnego użytku (Renfrew, Bahn 2002, 188). Należy jednak zaznaczyć, że pojmowanie źródeł funeralnych wyłącznie przez pryzmat wyposażenia grobowego niesie ze sobą pewne zagrożenie - skupianie uwagi tylko na analizie przedmiotów składanych ze zmarłym do grobu powoduje bowiem, że badana struktura społeczna jest kreślona wyłącznie przez pryzmat wyposażenia 
grobowego jako symbolu władzy (statusu/prestiżu) zmarłych. Zapomina się przy tym, że przedmioty umieszczane $\mathrm{w}$ grobie razem ze zmarłym mogły również odzwierciedlać jego tożsamość społeczną wynikającą z uwarunkowań biologicznych (płeć i wiek), jak i z pełnionych w społeczeństwie funkcji (Gryzińska-Sawicka 2014, 51).

W przypadku zachodniopodolskiej grupy RSK największą trudność, na jaką napotyka się przy ocenie pozycji społecznej zmarłego w oparciu o analizę składu towarzyszącego mu inwentarza, jest wyrabowanie większości zespołów grobowych. Efektem tego jest zubożenie ich wyposażenia grobowego o niektóre kategorie przedmiotów, a zwłaszcza te, które były najbardziej wartościowe z punktu widzenia rabusiów grobowych. Do tych ostatnich, jak wskazują na to znaleziska przedmiotów pochodzących z wykopów rabunkowych z innych terytoriów zajętych przez ugrupowania w typie ,scytyjskim” (o „scytyjskim” modelu kulturowym), należą m.in. wyroby wykonane $\mathrm{z}$ drogocennych metali (i ich stopów) i inne przedmioty o prestiżowym charakterze, a także elementy uzbrojenia ochronnego (pancerze) (np. Samokvasov 1908, 99, 120, fig. 45, 58). Wszystko to powoduje, że zachowane do chwili obecnej inwentarze są niekompletne - brak jest też możliwości ustalenia, jakie pierwotnie zabytki złożono ze zmarłym. Jeżeli chodzi o samą ocenę „bogactwa” (zamożności) inwentarza, to należy się skupić raczej na badaniu obecności (lub ich braku) kategorii funkcjonalnych przedmiotów, a nie ich ogólnej liczebności.

Wyżej zaprezentowane ograniczenia w przydatności wyposażenia grobowego dla badań nad zróżnicowaniem społecznym populacji zachodniopodolskiej grupy RSK w kontekście źródeł sepulkralnych powodują, że główny nacisk przy ich badaniu należy położyć na inne aspekty obrządku pogrzebowego stosowanego przez tę ludność. Najbardziej perspektywiczne wydają się być studia nad drugim z wyżej wymienionych czynników, jakim jest sposób pochówku. W badaniach tych główny nacisk kładzie się na analizę nakładu wydatku energii, czy też po prostu nakładu pracy przeznaczonej przez żałobników na wzniesienie konstrukcji grobowych i organizację ceremonii pogrzebowej (Tainter 1975, 1978; Peebles, Kus 1977; Mizoguchi 1993). Podstawą badań prowadzonych w tym kierunku jest założenie, zgodnie z którym sposób pochówku zależał do pozycji zmarłego w społeczeństwie - im wyższa była jego pozycja, tym osoby, które go chowały (żałobnicy), wydatkowały więcej energii na rytuał pogrzebowy. Zdaniem J. Taintera, który w swoich badaniach skupia uwagę właśnie na tym aspekcie obrzędowości pogrzebowej, wydatek energii jest obiektywną miara pozycji społecznej (statusu) zmarłego i dużo trafniej oddaje jego status niż wyposażenie grobowe. W tym miejscu należy zaznaczyć, że z założeniem tym dobrze koresponduje opis pochówku scytyjskiego wodza (reguł ceremoniału pogrzebowego stosowanego przy chowaniu scytyjskich władców? - por. Ivantchik 2011, 76) zawarty w D ziejach Herodota (IV, 71-73). Właśnie w nim pada kluczowe dla omawianej kwestii stwierdzenie: ,po załatwieniu tych czynności [tzn. złożeniu ciała zmarłego wraz z towarzyszącymi mu osobami zależnymi, końmi i darami grobowymi - M.B.] sypią wszyscy wielki kopiec, współzawodnicząc ze sobą i usiłując uczynić go jak największym" (Herodot IV, 71).

Wracając do kwestii strat energii przeznaczonej na wzniesienie konstrukcji grobowej i organizację ceremonii pogrzebowej, to sposób ich oceny może być różny (np. Fleming 1973, 180-185; Tainter 1975; Peebles, Kus 1977; Przybyła 2014, 16). Wśród badaczy zajmujących się archeologią scytyjską przy ocenianiu nakładu pracy włożonego w pogrzeb nacisk kładzie się przede wszystkim na badanie wielkości grobu. Istotne są tu cechy metryczne związane zarówno z właściwą konstrukcją grobową, w której złożono zmarłego, jak i nakrywającą go strukturą w postaci nasypu kurhanowego (np. Šul'ženko 1987, 144; Boltrik 2004; Romaško, Skoryj 2009, 90-95; Ivantchik 2011, 76-78, 80, 81, 83, tabela 3.1; tam też dalsza literatura). Również i te kryteria powinny zostać wzięte pod uwage w przypadku badań nad strukturą społeczną ludności zachodniopodolskiej grupy RSK. Jednocześnie trzeba zaznaczyć, że większą rolę należy położyć na analizę wielkości konstrukcji grobowej ${ }^{2}$ niż wielkość nasypu kurhanowego ${ }^{3}$. W tym ostatnim przypadku wysokość i średnica nasypu kurhanowego odnotowana przez badaczy rozkopujących dany zespół grobowy jest różna od tej pierwotnej;

2 W niniejszej publikacji termin ten używany jest dla opisu założonej na dawnej powierzchni lub wkopanej w ziemię budowli bezpośrednio przeznaczonej na złożenie w niej zmarłego jeszcze przed nakryciem jej nasypem kurhanowym.

3 Konstrukcja nadgrobowa budowana nad właściwym grobem. 
czynniki destrukcyjne mogą być zarówno pochodzenia naturalnego, jak i antropogenicznego (por. np. uwagi na temat niszczenia nasypów kurhanowych poczynione przez T. Sulimirskiego - 1936, 45-100). Znajdująca się w ich wnętrzu konstrukcja grobowa na ogół nie ulega natomiast takim przekształceniom - nawet jeżeli sama budowla zostanie zniszczona, to zawsze możliwe jest, oczywiście jeżeli cały zespół nie uległ daleko posuniętej destrukcji, zrekonstruowanie jej wielkości. Innym kryterium mogącym zostać użytym przy ocenie nakładu pracy włożonego $\mathrm{w}$ pogrzeb jest ocena złożoności konstrukcji grobowych. W przypadku analizowanego ugrupowania kulturowego odnotowano bowiem bardzo duże zróżnicowanie budowli grobowych (np. Sulimirski 1936, 5-9; Eberts 2012, 326-328, fig. 2.1). Zwraca uwage fakt, iż najbardziej złożone konstrukcje grobowe należą zarazem do największych.

Za mało przydatne dla badań nad zróżnicowaniem społecznym ludności zachodniopodolskiej grupy RSK należy uznać natomiast dane na temat stosowanych przez nią sposobów traktowania ciała zmarłego. Co prawda społeczności te charakteryzują się stosowaniem zróżnicowanych obrzędów grzebalnych (kremacja, inhumacja, birytualizmu, pochówki symboliczne; por. np. Sulimirski 1963, 9; Smirnova 2004, 419; Eberts 2012, 328-330, fig. 2.2.), to jednak badania nad nimi trudno uznać za perspektywiczne. Szczególnie duże wątpliwości budzi stosunkowo wysoki udział grobów bez ludzkich szczątków kostnych. Uwaga ta dotyczy przede wszystkim zespołów pochodzących z wykopalisk z końca XIX lub początku XX wieku oraz innych, które $\mathrm{z}$ różnych obiektywnych przyczyn nie zostały przebadane w sposób profesjonalny. Nie można bowiem wykluczyć, że szczątki kostne nie zostały z różnych względów uchwycone. Inną trudnością, na jaką napotyka się przy badaniu tego aspektu obrządku pogrzebowego, jest duży udział pochówków ciałopalnych. W ich przypadku podstawowym utrudnieniem jest brak danych antropologicznych, co w sposób zasadniczy utrudnia określenie nie tylko płci i wieku zmarłych, ale również ich ilość w grobie. Równocześnie należy zaznaczyć, że interpretacje pochówków ciałopalnych bez oparcia w danych antropologicznych mogą być zwodnicze. Świadczą o tym specjalistyczne badania pozostałości po kremacji odkrytych w grobie w miejscowości Byków. Wykazały one bowiem, że brak jest wśród nich pozostałości szczątków ludzkich - ujawnione w tym zespole kości należały nie do człowieka, ale do zwierząt (Mahnik et al. 2003, 353, 541).

Podsumowując powyższe obserwacje, wydaje się, że najbardziej zasadnymi dla badań nad podejmowanym zagadnieniem źródłami związanymi z obrządkiem pogrzebowym są zróżnicowanie wielkościowe i formalne konstrukcji grobowych oraz nakrywających je nasypów kurhanowych, a także, choć w mniejszym stopniu, analiza wyposażenia grobowego. Wskaźniki te należą do powszechnie stosowanych przy badaniu społeczeństw różnych ugrupowań scytyjskich (o „scytyjskich” cechach kulturowych) z terenów lasostepu (np. Šul'ženko 1987b, 179; Babenko 2005, 172-183; Bujnov, Okatenko 2013, 128) i stepu pontyjskiego (np. Rolle 1979, 33f.; Bunâtân 1985, 91-101; Boltrik 2004; Romaško, Skoryj 2009, 89-91).

Ze względu na fakt, iż wyżej wymienione wskaźniki w części przypadków mają charakter jakościowy (typ konstrukcji grobowej, przedmioty wchodzące w skład inwentarzy grobowych), a w części ilościowy (wielkości nasypów i konstrukcji grobowych), konieczne jest ich ujednolicenie. W tym celu, biorąc pod uwagę, że w dalszych analizach wykorzystywano metody statystyczne (analizy skupień i korespondencji), zdecydowano się na zmianę wskaźników ilościowych (wymiary konstrukcji grobowej i nasypów) na jakościowe. Łącznie wydzielono 48 cech obrządku pogrzebowego. Ich wykaz wraz $\mathrm{z}$ omówieniem podstaw wydzielania $\mathrm{w}$ przypadku niektórych ze zmiennych znajduje się na końcu publikacji (aneks numer 2).

\section{KLASYFIKACJA GROBÓW ZACHODNIOPODOLSKIEJ GRUPY RSK}

\subsection{Analiza skupień}

Jak już wcześniej zaznaczono, zgodnie z jednym $\mathrm{z}$ fundamentalnych założeń archeologii społecznej, struktura społeczna może być odzwiercie- dlona poprzez zróżnicowanie grobów. Szczególnie istotne dla tej problematyki jest stwierdzenie, zgodnie z którym osoby należące do różnych grup społecznych mogły chować swoich zmarłych w różny sposób, odmienny dla poszczególnych 
grup (O’Shea 1984, 33-34). W materiale archeologicznym grupom tym powinny odpowiadać różne zbiory pochówków. Dla badań nad strukturą społeczną szeroko rozumianych Scytów (i ugrupowań o ,scytyjskim” modelu kulturowym) ważne jest to, że istnienie różnych zwyczajów pogrzebowych, w zależności od przynależności do określonej grupy społecznej (,władcy” - „zwykli” Scytowie), jest poświadczone przez źródła pisane (Herodot IV, 7173). Ze źródłami tymi bardzo dobrze korespondują znaleziska archeologiczne z całego obszaru pontyjskiego (konfrontacja tekstu Herodota ze źródłami archeologicznymi - Ivantchik 2011, tam też dalsza literatura). Głównym zadaniem tej części publikacji jest próba uchwycenia grup pochówków, które można łączyć z różnymi grupami społecznymi. W tym celu dokonano klasyfikacji 100 grobów, dla których dysponowano danymi pozwalającymi na opisanie ich według wcześniej wydzielonych cech obrządku pogrzebowego (aneks 1). Cechy te ze względu na swój charakter (dane nominalne oznaczające obecność lub nieobecność danej cechy w określonym zespole grobowym) pozwoliły następnie na stworzenie matrycy wyjściowych danych, w której poszczególne zespoły grobowe opisywane były w sposób ,zero-jedynkowy”, gdzie „1” oznaczało obecność określonej cechy, natomiast „,0" - jej brak.

Właściwa systematyzacja grobów została przeprowadzona $\mathrm{z}$ wykorzystaniem analizy skupień będącej podstawową metodą klasyfikacji wykrywająca strukturę analizowanych informacji. Przy formowaniu skupień wykorzystano z kolei metodę Warda jako najbardziej efektywną procedurę, umożliwiająca porównanie obiektów wielocechowych i przedstawiająca najbardziej naturalne skupiska badanych obiektów (Dwight 1989, 44-47; Renfrew, Bahn 2002, 189; Baxter 2015, 148-168). W przypadku analizowanych zespołów grobowych chodziło przede wszystkim o ich pogrupowanie na w miarę możliwości najbardziej podobne do siebie klasy (grupy), ze względu na wyżej wyznaczone cechy obrządku pogrzebowego.

Przed przystąpieniem do omówienia wyników analizy skupień należy zaznaczyć, że ze względu na niewystarczającą do badań statystycznych ilość zespołów grobowych, które można łączyć z określonymi grupami biologicznymi (jednostkowe pochówki męskie, kobiece i dziecięce, pochówki podwójne i zbiorowe) zdecydowano się na łączne potraktowanie wszystkich 100 badanych kompleksów. Rezultaty przeprowadzonej analizy skupień przedstawia rycina $\mathrm{nr} 1^{4}$. Szczegółowe badanie zespołów pogrupowanych metodą Warda pozwoliło określić najbardziej podobne do siebie pod względem wyznaczonych cech obrządku pogrzebowego. Wykonano dwa przecięcia. Pierwsze zrobiono na 8 odległości wiązania i na tej podstawie wydzielono cztery główne grupy (klastery). Na dendrogramie oznaczono je cyframi od 1 do 4 . Różnią się one między sobą wymiarami konstrukcji grobowych, wielkością nakrywających je nasypów oraz lokalizacją pochówków w obrębie nasypu. Dalsza analiza zespołów zgrupowanych w ramach poszczególnych klasterów wykazała istnienie w ich obrębie mniejszych zbiorów (podklasterów) różniących się między sobą, poza cechami wielkościowymi, składem umieszczanego w nich inwentarza, a w mniejszym stopniu złożonością konstrukcji grobowych. Przeprowadzona pod tym kątem analiza wykazała, że najbardziej optymalne miejsce przecięcia dendrogramu znajduje się mniej więcej na 4 i 2/3 odległości wiązania - na tej podstawie wydzielono 12 grup grobów (podklasterów). Grupy te oznaczono literami A, B, C i D, umieszczonymi po cyfrze oznaczającej numer głównego skupienia (klastera), w obrębie którego się one wydzielają. Szczegółową charakterystykę wydzielonych grup pochówków prezentuje tabela 1 .

Analiza informacji zawartych w tej tabeli prowadzi do kilku spostrzeżeń. Po pierwsze, wśród wydzielonych grup grobów zaobserwować można pewne korelacje pomiędzy wielkością nasypów kurhanowych oraz powierzchnią i złożonością konstrukcji grobowych a zróżnicowaniem ilościowym i jakościowym inwentarza - groby o niewielkich rozmiarach, nakrywane małymi nasypami zawierają ubogie inwentarze (1-3 kategorie funkcjonalne przedmiotów; grupy 4.C i 4.D), podczas gdy najbardziej zróżnicowane wyposażenie grobowe charakteryzuje zespoły o największych (grupa 2.D) i/lub najbardziej złożonych konstrukcjach grobowych (grupy 1.B, 2.B, 2.C). Pomiędzy nimi znajduje się cały szereg zespołów grobowych, które można określić jako zakładane w średniej wielkości konstrukcjach grobowych i ,średnio” wyposa-

4 Oznaczeniami literowymi i cyframi oznaczono poszczególne analizowane zespoły grobowe. Wykaz skrótów umieszczono na końcu publikacji, w wykazie grobów uwzględnionych w analizach (aneks nr 1). Analogiczne oznaczenia umieszczono także w tabelach i na pozostałych rycinach. 


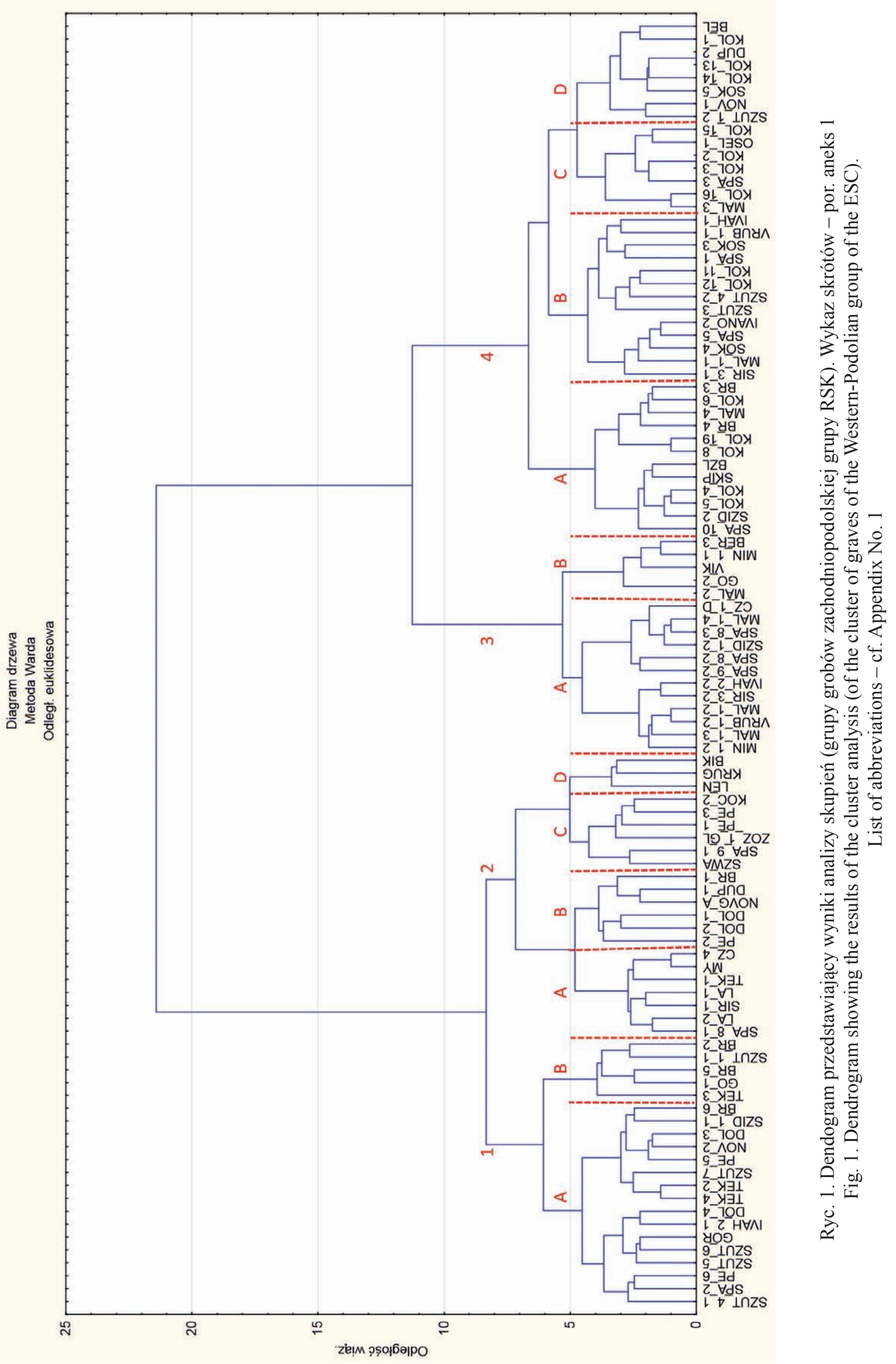


żone (grupy 1.A, 2.A i 4.B - łącznie 36 grobów). Po drugie, różnice pomiędzy poszczególnymi wydzielonymi grupami pochówków widoczne w składzie inwentarza wskazują na zróżnicowanie ekonomiczne (majątkowe) badanej ludności (groby ubogo wyposażone - groby średnio wyposażone - groby bogato i bardzo bogato wyposażone). Jednocześnie w inwentarzach niektórych grup obecne są wskaźniki świadczące o funkcji społecznej zmarłego. Pod tym względem szczególnie charakterystyczne sa zespoły grup 1.A, 1.B, 2.B, 2.C i 2.D (i pojedyncze grupy 4.B) zawierające $\mathrm{w}$ wyposażeniu co najmniej dwa elementy uzbrojenia zaczepnego lub pancerze - groby te można przypisać wojownikom. Równocześnie zespoły te należą do najbogatszych oraz umieszczane są w największych konstrukcjach grobowych. Kolejną obserwacją, płynącą z analizy informacji zawartych $w$ tabeli 1 jest stwierdzenie związku pomiędzy niektórymi grupami grobów a płcią zmarłych - pochówki grup 2.A i 2.D, sądząc po inwentarzu, należały do mężczyzn, podczas gdy groby grupy 4.C zawierają wyłącznie wyposażenie grobowe o żeńskim charakterze. Dodatkowo należy zaznaczyć, że jednostkowe pochówki dziecięce (nastolatków) występują wyłącznie w grupach 3.A (3 groby) i 4.D (1 pochówek).

Podsumowując powyższe obserwacje, należy stwierdzić, że wydzielone grupy grobów wykazują pewne cechy pozwalające na utożsamienie ich z miejscami pochówków osób należących do różnych grup społecznych. Tym samym można przyjąć założenie, że populacja zachodniopodolskiej grupy RSK charakteryzowała się złożoną strukturą społeczną. Jednocześnie należy zaznaczyć, że pomiędzy częścią wydzielonych zbiorów (grup) grobów widoczne są daleko idące podobieństwa, przy czym najbardziej podobne do siebie grupy nie zawsze muszą być zgrupowane w ramach jednego z czterech głównych skupień (klasterów). Najbardziej podobne do siebie grupy grobów można połączyć w większe zbiory - klasy.

\subsection{A naliza porównawcza wydzielonych grup grobów}

Kolejnym etapem badania było przeprowadzenie analizy porównawczej wyżej wydzielonych grup pochówków w celu ich usystematyzowania. Punktem wyjścia dla tej części analiz jest definicja stratyfikacji społecznej - w socjologii termin ten oznacza sposób hierarchizacji społeczeństwa według zajmowanej pozycji społecznej. Stratyfikacja społeczna opiera się zatem na hierarchii społecznej stanowiącej klasyfikację jednostek lub grup socjalnych pod względem malejącej zamożności, władzy i prestiżu społecznego (Brémond et al. 2006, 167).

Jak już wcześniej zaznaczono, w przypadku ugrupowań scytyjskich (o „scytyjskim” modelu kulturowym) jednym z czynników mogących odzwierciedlać pozycję społeczną zmarłych jest nakład pracy przeznaczony na dokonanie ceremonii pogrzebowej włącznie $\mathrm{z}$ wybudowaniem grobu. Z drugiej strony należy zaznaczyć, że obserwacje poczynione $\mathrm{w}$ trakcie wyżej przeprowadzonych analiz, a także analogiczne spostrzeżenia dla innych społeczności w typie „scytyjskim” wykazały, że z wielkością grobów (zwłaszcza ich powierzchnią) idą w parze ,zamożność” (zróżnicowanie ilościowe i jakościowe) złożonego w nim wyposażenia grobowego. Tym samym wydzielone grupy grobów, czy też ich większe zbiory (klasy), należy uszeregować w taki sposób, aby w stworzonym systemie najwyższe miejsce zajmowały te zespoły grobowe, w przypadku których poniesiono największe nakłady energii na ich wybudowanie, a ich inwentarze należą do najbogatszych i najbardziej zróżnicowanych. Wraz z przechodzeniem do niższych klas, tworzace je grupy grobów powinny charakteryzować się zmniejszaniem nakładu pracy (mniejsze i prostsze konstrukcje grobowe i nasypy kurhanowe), a ich inwentarze powinny być odpowiednio uboższe. Najniższe miejsce $\mathrm{w}$ tworzonej $\mathrm{w}$ ten sposób hierarchii powinny zajmować najmniejsze i najprostsze groby o najuboższych inwentarzach.

Analizy porównawcze wydzielonych grup grobów w celu ich uszeregowania według wyżej określonej kolejności wymagaja pewnej standaryzacji i obliczeń. Dlatego też pierwszym etapem tego badania było stworzenie rankingów odzwierciedlających oba wyżej wymienione elementy ceremonii pogrzebowej. Przy oszacowaniu nakładu pracy przeznaczonej na wybudowanie grobu pod uwagę wzięto wysokość i średnicę nasypu kurhanowego oraz wielkość (powierzchnię) znajdujących się pod nimi konstrukcji grobowych, kładąc przy tym szczególny nacisk na to ostatnie kryterium. Bardziej problematycznie rysuje się natomiast kwestia oceny „bogactwa” wyposażenia grobowego. Jak już to wcześniej zaznaczono, podstawową trudnością, na jaką napotykają analizy przeprowadzone pod tym kątem, jest wyrabowanie (niekiedy nawet dość 
istotne) części zespołów grobowych. $\mathrm{Z}$ tego powodu przy oszacowaniu „bogactwa” zdecydowano się na użycie takich metod analitycznych, które skupiają się przede wszystkim na badaniu obecności określonych kategorii funkcjonalnych przedmiotów. Spośród różnych propozycji oszacowania różnorodności inwentarza (np. Ciecielska 2002, 61-62; Przybyła 2014, 11-14) zdecydowano się na zastosowanie dwóch metod badawczych - „NAT” (Number of Different Arteffact Types) i ,współczynnika splendoru". Pierwsza z tych metod została wykorzystana przez L. Hedeager $(1978 ; 1992)$ dla pochówków z okresu rzymskiego z obszarów Skandynawii. Istotą stworzonej przez nią metody jest określenie ilości kategorii funkcjonalnych przedmiotów w grobie. Przykładowo wartość wskaźnika NAT dla grobu wyposażonego w jedną kościaną szpilę i trzy złote zapinki wynosić będzie 2, ponieważ znalazły się w nim dwie różne kategorie funkcjonalne. Tym samym dla oceny różnorodności wyposażenia grobowego nie jest ważna ilość wchodzących w jego skład artefaktów, ale ilość różnych funkcjonalnych kategorii przedmiotów. Jako bogate zespoły grobowe, należące do zmarłych o wyższym statusie, uznawane są te, w inwentarzach których występuje duża ilość różnych typów przedmiotów, która przyczynia się do wysokiej wartości NAT. Zbliżony sposób oceny wskaźnika różnorodności inwentarza (jego bogactwa) użyty został przez F. R. Hodsona (1977) przy analizie cmentarzyska w Hallstatt. Celem tej procedury, nazwanej przez niego metodą „współczynnika splendoru”, jest ujawnienie, które rodzaje zabytków koncentrują się wyłącznie w najbogatszych zespołach grobowych. Podobnie jak w przypadku wskaźnika NAT, również przy określaniu współczynnika splendoru brana jest pod uwagę wyłącznie obecność $\mathrm{w}$ grobie przedmiotów należących do różnych kategorii funkcjonalnych. Inny jest natomiast sposób oceny wartości „bogactwa" inwentarza. W tym przypadku bowiem zwraca się uwagę na współwystępowanie poszczególnych typów funkcjonalnych przedmiotów $\mathrm{z}$ innymi kategoriami. Za wartość punktową kolejnych kategorii funkcjonalnych zabytków przyjmuje się średnią ilość różnych typów przedmiotów inwentarza w grobach zawierających te artefakty. Przykładowo, na badanym przez F. Hodsona cmentarzysku w Hallstatt miecze wystapiły w 10 grobach zawierających średnio 4,6 różnych kategorii funkcjonalnych przedmiotów, co daje wartość punktową dla mieczy równą 4,6. Punktację całych inwentarzy określa się, sumując pozyskane w ten sposób wartości punktowe, bez uwzględnienia, podobnie jak to ma miejsce w przypadku wskaźnika NAT, frekwencji występowania poszczególnych kategorii zabytków. Wartości punktowe obliczone dla poszczególnych kategorii źródeł zaprezentowane zostały w tabeli $2^{5}$.

Przy tworzeniu rankingów grup grobów ze względu na nakład pracy (rankingi „wysokość nasypu”, ,średnica nasypu”, ,powierzchnia konstrukcji grobowej”) i zróżnicowanie („bogactwo”) inwentarzy (rankingi ,punktacja NAT” i ,współczynnik splendoru") posłużono się wykresami typu ramkawąsy (ryc. 2-6). Poszczególne grupy umiejscowione zostały na nich w kolejności od największej do najmniejszej średniej wartości badanego wskaźnika. Zastosowanie takiego sposobu prezentacji rozkładu wartości poszczególnych wskaźników dla każdej z badanych grup grobów pozwoliło nie tylko na ich uszeregowanie, ale również umożliwiło ich porównanie ze sobą. W tym ostatnim przypadku zwraca uwagę fakt, iż rozkłady wartości badanych wskaźników dla niektórych grup są ze sobą zbieżne. Obserwacja ta potwierdza poczynione już wcześniej spostrzeżenia odnośnie do łączenia się części grup wydzielonych za pomocą analizy klasterowej w większe zbiory (klasy). W zależności od badanego wskaźnika wydzielono od pięciu do siedmiu takich klas. Numeracja poszczególnych zbiorów (względnie pojedynczych grup grobów) jest tożsama z pozycją zajmowaną przez daną grupę w określonym rankingu.

Poza klasyfikacją grup grobów ze względu na zajmowaną przez nie pozycję w poszczególnych rankingach, przy analizach porównawczych wzięto pod uwagę również inne zmienne. Należą do nich zróżnicowanie typów konstrukcji grobowych występujących w poszczególnych grupach oraz częstotliwość występowania określonych kategorii funkcjonalnych przedmiotów. Te ostatnie rozpatrywano $\mathrm{w}$ ramach trzech grup. Pierwszą z nich stanowia tzw. przedmioty prestiżowe, manifestujące status

5 W tym miejscu należy zaznaczyć, że poza zabytkami uwzględnionymi w wykazie cech (aneks 2), a więc takich które wystapiły w co najmniej trzech badanych grobach, w przypadku obu metod uwzględniono także ciosła, które wystapiły w dwóch zespołach. Dodatkowo przy obliczaniu współczynnika splendoru pod uwagę wzięte zostały także zabytki będące importami z szeroko pojętego środowiska środkowoeuropejskiego. 


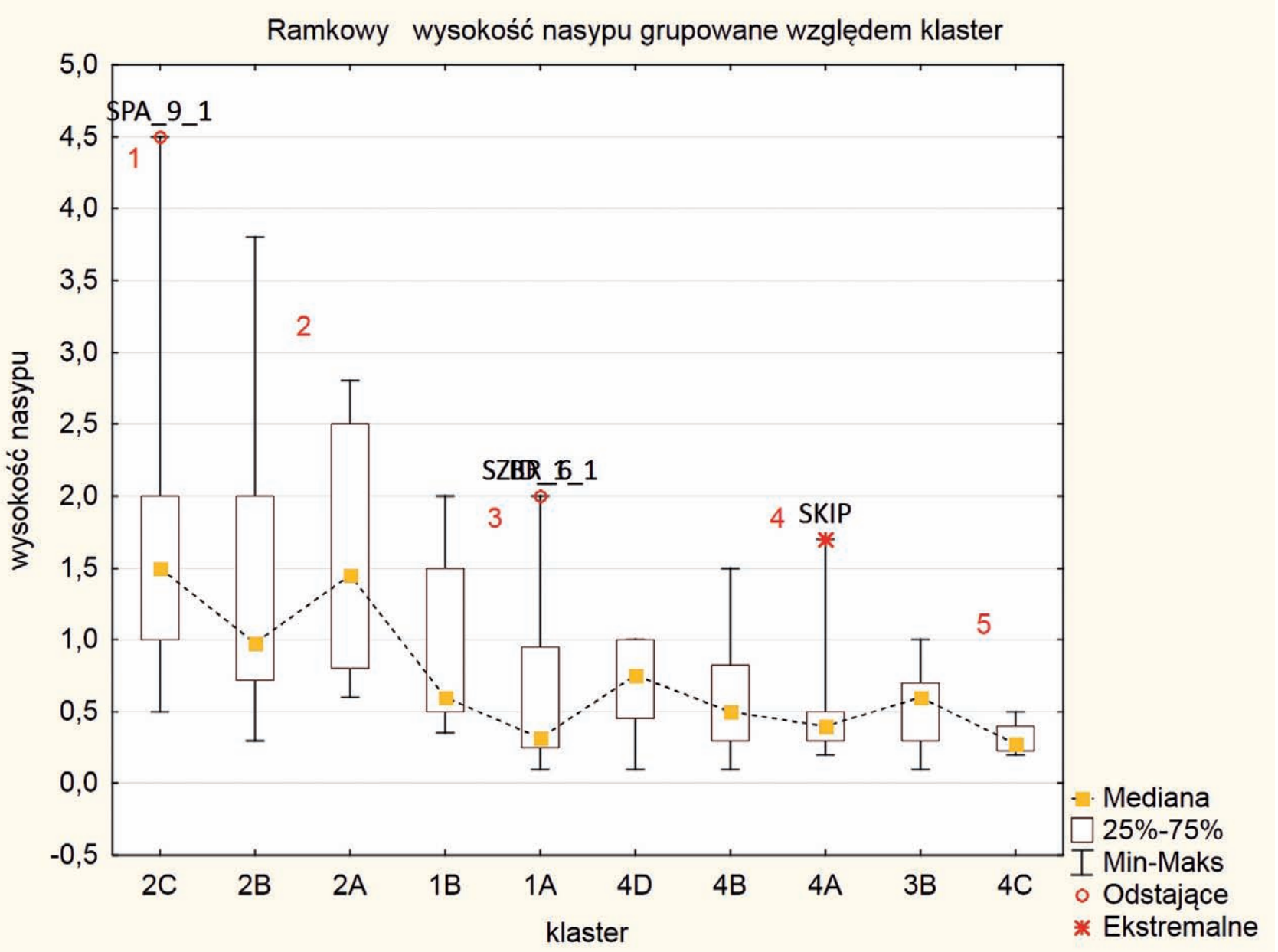

Ryc. 2. Wykres ramkowy przedstawiający ranking „wysokość nasypów kurhanowych” dla grup grobów wydzielonych za pomocą analizy skupień. Czerwonymi cyframi zamieszczonymi na wykresie oznaczono pozycję w rankingu kolejnych grup grobów

Fig. 2. Frame chart showing "the height of burial mounds" ranking for groups of graves separated by the cluster analysis. Red numbers on the chart indicate the position in the ranking of the consecutive groups of graves

społeczny właściciela. Zgodnie z poglądami na ten temat funkcjonującymi $\mathrm{w}$ gronie badaczy zajmujących się szeroko pojętą problematyką scytyjską, wśród zabytków spotykanych w inwentarzach zachodniopodolskiej grupy RSK za takie uznać należy przede wszystkim przedmioty wykonane z drogocennych metali (złoto) i ich stopów (elektron) oraz naczynia brązowe, a zwłaszcza kotły. Poza nimi do grupy tej można odnieść także takie kategorie funkcjonalne jak brązowe noże ofiarne i elementy wozów oraz zabytki o proweniencji obcej niż miejscowa lub „scytyjska”; do tych ostatnich, poza wyrobami pochodzącymi z greckich warsztatów rzemieślniczych (np. złota zausznica z kurhanu nr 2 z Perebykivci, niektóre typy brązowych zwierciadeł), należą przede wszystkim importy (z wyłą- czeniem naczyń glinianych) z szeroko rozumianego środowiska środkowoeuropejskiego. Niewątpliwie wśród innych kategorii zabytków, których występowanie można łączyć z wysoką pozycją (społeczną lub majątkową) zmarłego, wymienić należy także elementy uprzęży, broń obuchową oraz elementy uzbrojenia ochronnego (pancerze). O wyjątkowym charakterze wszystkich wymienionych do tej pory przedmiotów świadczy nie tylko ich niewielka liczba (ryc. 7), ale również ich koncentracja $\mathrm{w}$ grobach o najbardziej zróżnicowanych inwentarzach, czego przejawem są ich wysokie wartości współczynnika splendoru (co najmniej 6,4 punktu; por. tabela 2).

Druga grupę kategorii funkcjonalnych przedmiotów inwentarza uwzględnionych $\mathrm{w}$ analizach 


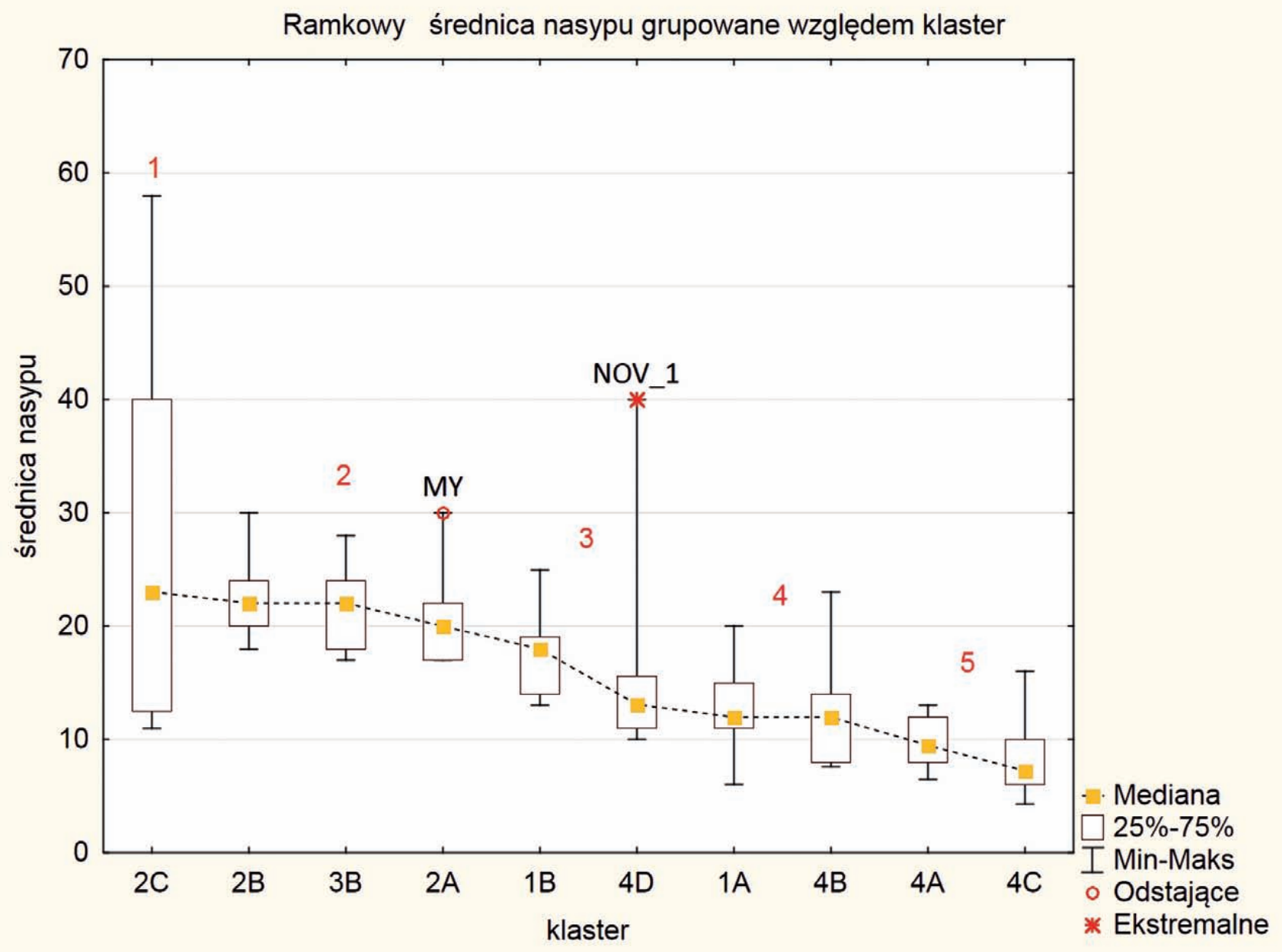

Ryc. 3. Wykres ramkowy przedstawiający ranking ,średnica nasypów kurhanowych” dla grup grobów wydzielonych za pomocą analizy skupień. Czerwonymi cyframi zamieszczonymi na wykresie oznaczono pozycję w rankingu kolejnych grup grobów

Fig. 3. Frame chart showing "the diameter of burial mounds" ranking for groups of graves separated by the cluster analysis. Red numbers on the chart indicate the position in the ranking of the consecutive groups of graves

porównawczych poszczególnych grup grobów stanowią militaria i elementy uprzęży, trzecią - zabytki o „żeńskim” charakterze (ozdoby, przęśliki, brązowe zwierciadła i kamienne półmiski). Należy przy tym zaznaczyć, że zarówno w przypadku militariów, jak i przedmiotów o „żeńskim” charakterze ważna jest nie tyle obecność w badanej grupie grobów konkretnego typu zabytku, co raczej występowanie w nich ich określonych zestawów. Różnice w składzie obu tych grup przedmiotów mogą odzwierciedlać zarówno różną pozycję majątkową zmarłych mężczyzn i kobiet, jak również ich przynależność do określonych grup społecznych (grupy o różnej pozycji społecznej) i funkcjonalnych (np. różne struktury w obrębie warstwy wojowników - por. np. Burghardt 2015, 159-160, tabela 5).
Na podstawie analizy porównawczej przeprowadzonej pod kątem wyżej wymienionych czynników, liczbę 12 wydzielonych przy użyciu analizy klasterowej grup grobów zmniejszono do sześciu większych zbiorów (klas). Otrzymane w ten sposób klasy grobów zostały następnie ułożone zgodnie $\mathrm{z}$ wyżej przedstawioną definicją stratyfikacji (hierarchii) społecznej, a więc w taki sposób, aby przy przechodzeniu do kolejnych klas (od I do VI) zmniejszał się nakład pracy przeznaczonej na wybudowanie konstrukcji grobowych i nakrywających je nasypów kurhanowych, a ich inwentarze były coraz „uboższe” (mniej zróżnicowane ilościowo i jakościowo). Charakterystykę poszczególnych klas grobów, wraz z podstawami ich wydzielania, przedstawia tabela 3 . 


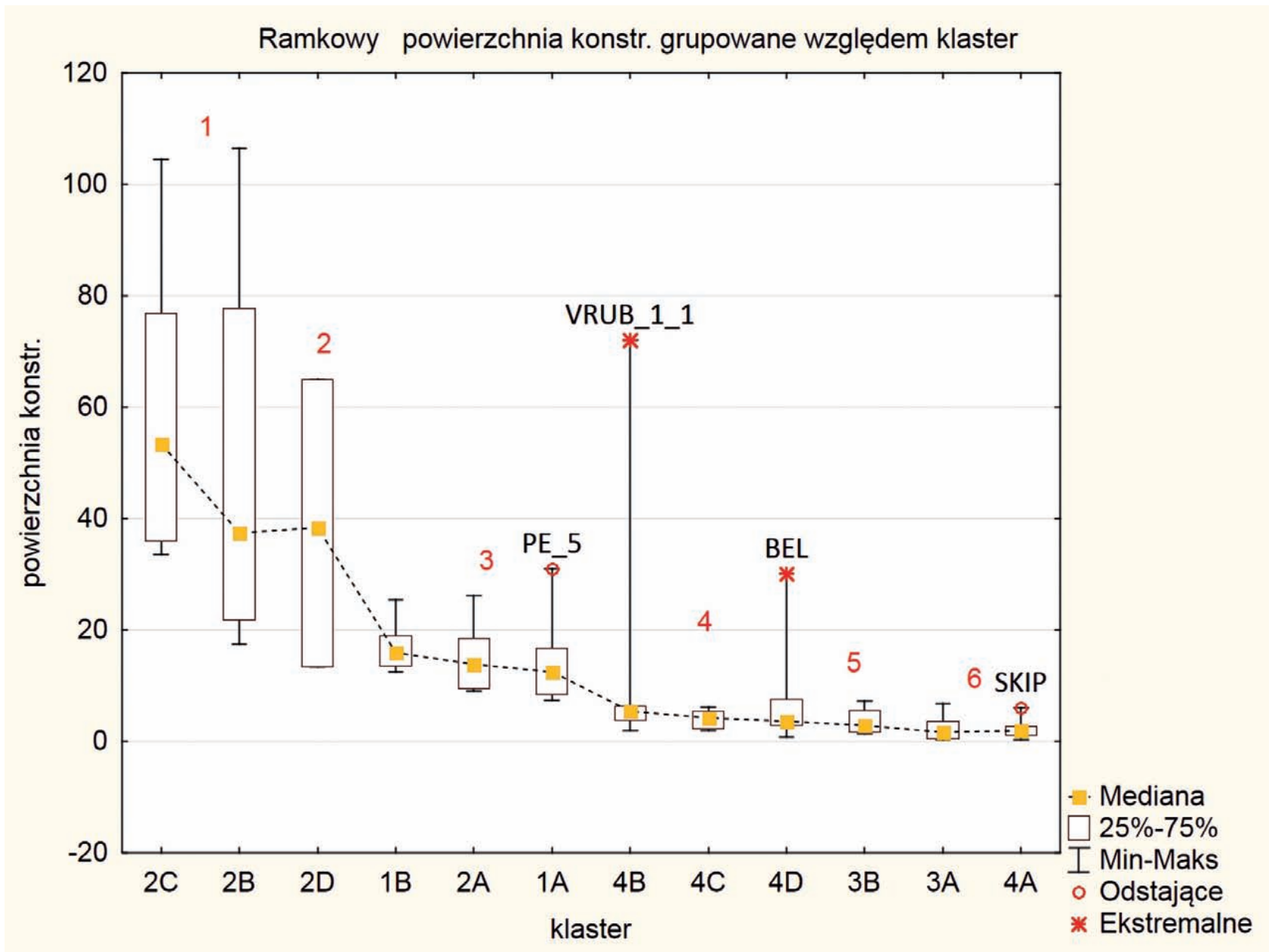

Ryc. 4. Wykres ramkowy przedstawiający ranking ,powierzchnia konstrukcji grobowych” dla grup grobów wydzielonych za pomocą analizy skupień. Czerwonymi cyframi zamieszczonymi na wykresie oznaczono pozycję w rankingu kolejnych grup grobów

Fig. 4. Frame chart showing "the surface of burial constructions" ranking for groups of graves separated by the cluster analysis. Red numbers on the chart indicate the position in the ranking of the consecutive groups of graves

\subsection{A naliza korespondencji}

Ostatnim etapem analiz zróżnicowania społecznego ludności zachodniopodolskiej grupy RSK w świetle źródeł sepulkralnych było zweryfikowanie stworzonej na podstawie analizy skupień klasyfikacji grobów. Do tego celu wykorzystano analizę korespondencji. Metoda ta, podobnie jak analiza skupień, należy do grupy wielowymiarowych metod analizy współwystępowania. Umożliwia ona opisanie zależności między zmiennymi i obiektami, na których przeprowadzono obserwację. Jej największą zaletą jest możliwość czytelnej, graficznej prezentacji współwystępowania kategorii zmiennych (Zimmermann 1997, 9-15; Baxter 2015, 133-147). Przy analizie tej wyko- rzystano tę samą matrycę danych, co w przypadku analizy skupień. Wyniki przeprowadzonej analizy korelacji przedstawia wykres na rycinie 8 . Na wykresie tym przedstawiono stopień korespondencji między zmiennymi symbolizującymi badane cechy obrządku pogrzebowego oraz pomiędzy poszczególnymi zespołami.

Jak wynika z ryciny 8 , rezultaty analizy korespondencji w zasadzie są zbieżne z wynikami wcześniejszych analiz-zarówno 12 grup zdefiniowanych za pomocą analizy skupień, jak również sześć klas grobów wyróżnionych w toku dalszej klasyfikacji tych grup, tworzy wydzielające się, przynajmniej częściowo, skupiska. Tylko w nielicznych przypadkach zespoły związane $\mathrm{z}$ daną grupa/klasą grobów znajdują się poza ich głównymi skupiskami. Uwa- 


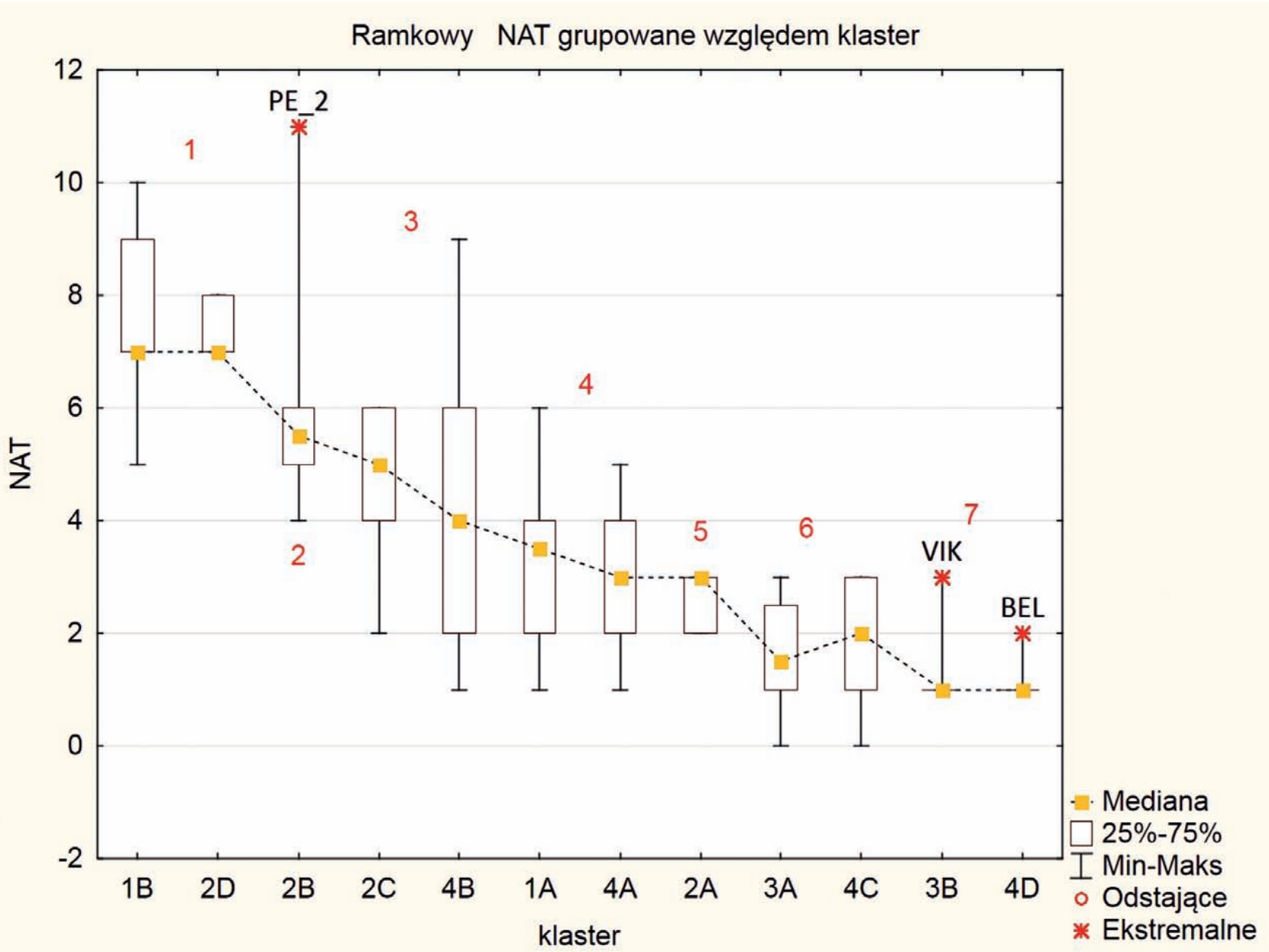

Ryc. 5. Wykres ramkowy przedstawiający ranking „punktacja NAT” dla grup grobów wydzielonych za pomocą analizy skupień. Czerwonymi cyframi zamieszczonymi na wykresie oznaczono pozycję w rankingu kolejnych grup grobów

Fig. 5. Frame chart showing "the NAT points" ranking for groups of graves separated by the cluster analysis.

Red numbers on the chart indicate the position in the ranking of the consecutive groups of graves

ga ta dotyczy przede wszystkim dwóch zbiorów pochówków: pierwszym $z$ nich są zaklasyfikowane do klasy III zespoły grupy 4.B, drugim - związane $\mathrm{z}$ klasą II groby grupy 1.A. W przypadku tych ostatnich, choć wszystkie pięć tworzących tę klasę grobów znajduje się po lewej stronie osi pierwszej, to nie tworzą one jednak wyraźnego skupiska - trzy z nich zlokalizowane są tuż przy samej osi w obrębie największego zagęszczenia zespołów klasy III, dwa pozostałe skupiają się natomiast w pewnym oddaleniu od niej, już w obrębie zespołów klasy I. Jeszcze bardziej na lewo od osi pierwszej oddalone są pozostałe zespoły związane z klasą II należące do grupy 2.D. Analiza porównawcza wszystkich trzech skupisk wykazała, że podstawowym elementem różnicującym te zespoły są zestawy umieszczonego w nich wyposażenia grobowego - bliżej osi znalazły się zespoły z inwentarzami o „kobiecym” charakterze, natomiast $\mathrm{w}$ dalszej odległości od niej znalazły się groby, w których głównym elementem wyposażenia są zestawy uzbrojenia zaczepnego. Abstrahując od czynników powodujących takie a nie inne umiejscowienie wzmiankowanych zespołów klasy II na tablicy korespondencji, należy zaznaczyć, że skupiska grobów grup 2.A i 4.B zlokalizowane są po obu stronach największego zagęszczenia zespołów klasy I. W świetle tej obserwacji pojawia się pytanie, czy zasadnym jest traktowanie obu tych klas rozdzielnie, czy też nie należałoby raczej potraktować ich jako jeden zbiór, jak sugeruja to wyniki analizy korespondencji. Rozstrzygnięcie tej kwestii przyniosło szczegółowe porównanie wszystkich zespołów tworzących omawiane klasy. Badanie to wykazało, że najbardziej wyróżniająca 


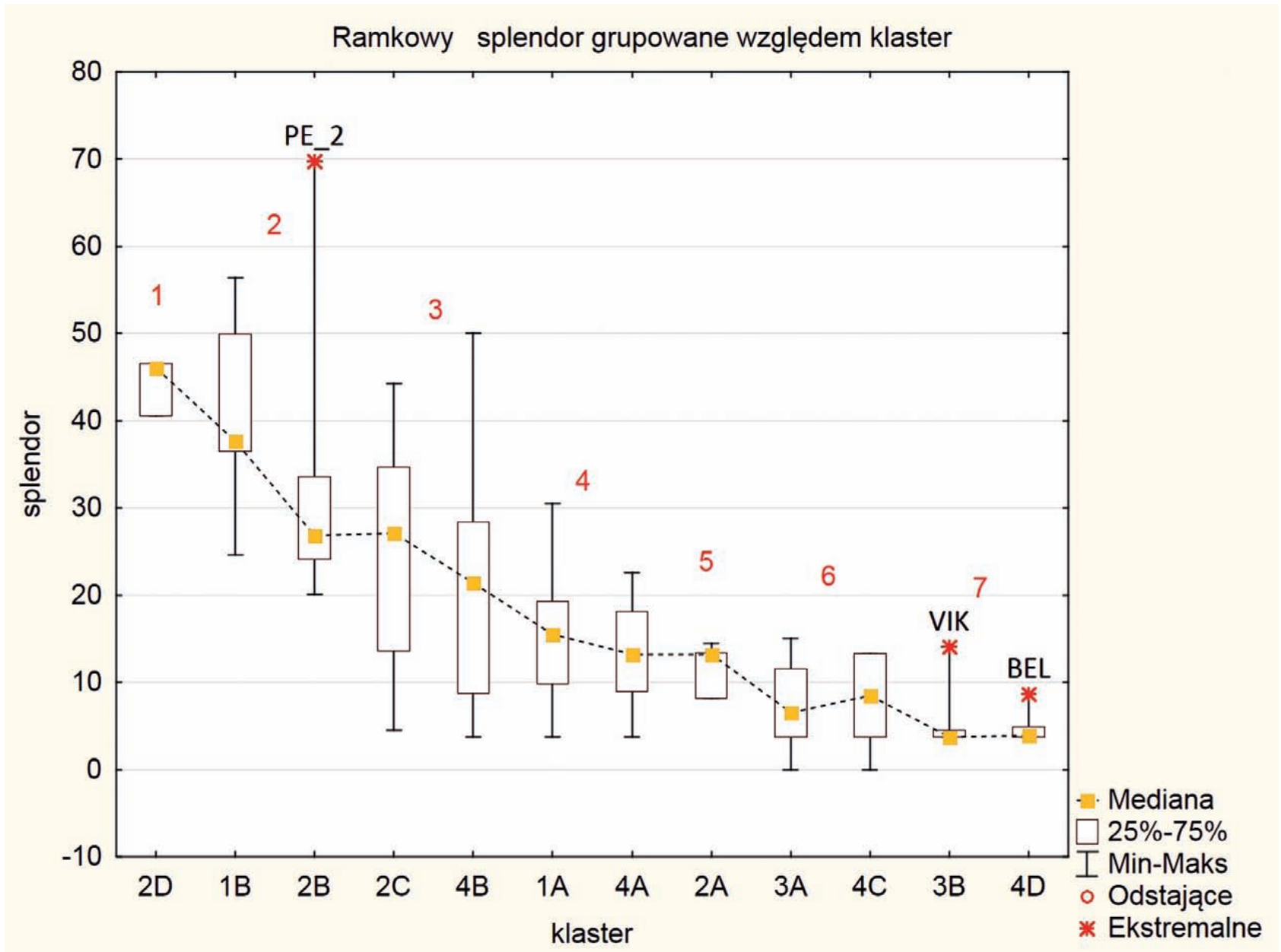

Ryc. 6. Wykres ramkowy przedstawiający ranking „współczynnik splendoru” dla grup grobów wydzielonych za pomocą analizy skupień. Czerwonymi cyframi zamieszczonymi na wykresie oznaczono pozycję w rankingu kolejnych grup grobów

Fig. 6. Frame chart showing "the splendour coefficient" ranking for groups of graves separated by the cluster analysis. Red numbers on the chart indicate the position in the ranking of the consecutive groups of graves

się grupę stanowi pięć grobów zakładanych w najbardziej złożonych grobowcach typów 11 i 12 (cechy 19 i 20) o powierzchniach wynoszących co najmniej $45 \mathrm{~m}^{2}$ oraz znacznej wysokości niektórych z nakrywających je nasypów kurhanowych (cecha 3). Jednocześnie zespoły te charakteryzują się obecnością jednych z najbogatszych i najbardziej zróżnicowanych inwentarzy. Zwraca uwagę fakt, iż wszystkie pięć zespołów o takich cechach zlokalizowanych jest na samej krawędzi lewego ramienia paraboli, po zewnętrznej stronie osi wyznaczonej przez punkty oznaczające cechy nr 31 (na górze) i 3 (na dole). Dodatkowo zespoły te znajdują się poza strefą wyznaczoną przez skupisko grupy 2.D, która została zaliczona do klasy II. W świetle tych obserwacji wydaje się, że najbardziej zasadne bę- dzie ograniczenie klasy I wyłącznie do wyżej scharakteryzowanych pięciu zespołów, podczas gdy pozostałe groby pierwotnie związane $\mathrm{z}$ tym zbiorem należy włączyć do klasy II.

Nieco inaczej wygląda natomiast kwestia lokalizacji grobów grupy 4.B. W oparciu o analizę porównawczą (tabela 3) zespoły tej grupy włączono wraz z grobami grup 1.A i 2.A do klasy III. Analiza tablicy korespondencji wykazała natomiast, że tylko siedem z 13 grobów tej grupy znalazło się w zbiorze związanym z tą klasą. Pozostałe sześć grupuje się wśród zespołów odnoszących się do innych klas - IV i V (po 3 zespoły). We wszystkich sześciu przypadkach o lokalizacji części grobów grupy 4.B w obrębie skupisk związanych z wymienionymi klasami decydują takie cechy jak konstruk- 
cje grobowe prostszych typów oraz niezbyt bogate i zróżnicowane inwentarze $\mathrm{z}$ dominacją zabytków niecharakterystycznych lub tych o żeńskim charakterze. Analiza porównawcza wszystkich zespołów grupy 4.B z innymi grobami zlokalizowanymi w ramach poszczególnych skupisk oznaczonych jako klasy III, IV i V wykazała, że najbardziej właściwe będzie nie, jak to sugerowały wcześniejsze analizy, traktowanie ich wszystkich jako związanych z jedną klasą (klasa III), ale ich rozdzielenie pomiędzy wszystkie trzy zbiory, w których one wystąpiły. Wyjątek stanowi jedynie grób nr 1 z kurhanu nr 3 z miejscowości Serwatyńce, który znalazł się wśród zespołów klasy V. Pod względem „,bogactwa" wyposażenia jest on bardziej zbliżony do grobów klasy IV - zespół ten zawiera sześć różnych

\author{
口złoto/elektron (7) \\ 口n. brązowe (2) \\ $\square$ czekan, topór (5) \\ $\square$ uzbrojenie ochronne (6)
}

\author{
$\square$ noże ofiarne, elementy wozów cer. (3) \\ $\square$ importy środ.europ. (4) \\ uprząż (12)
}
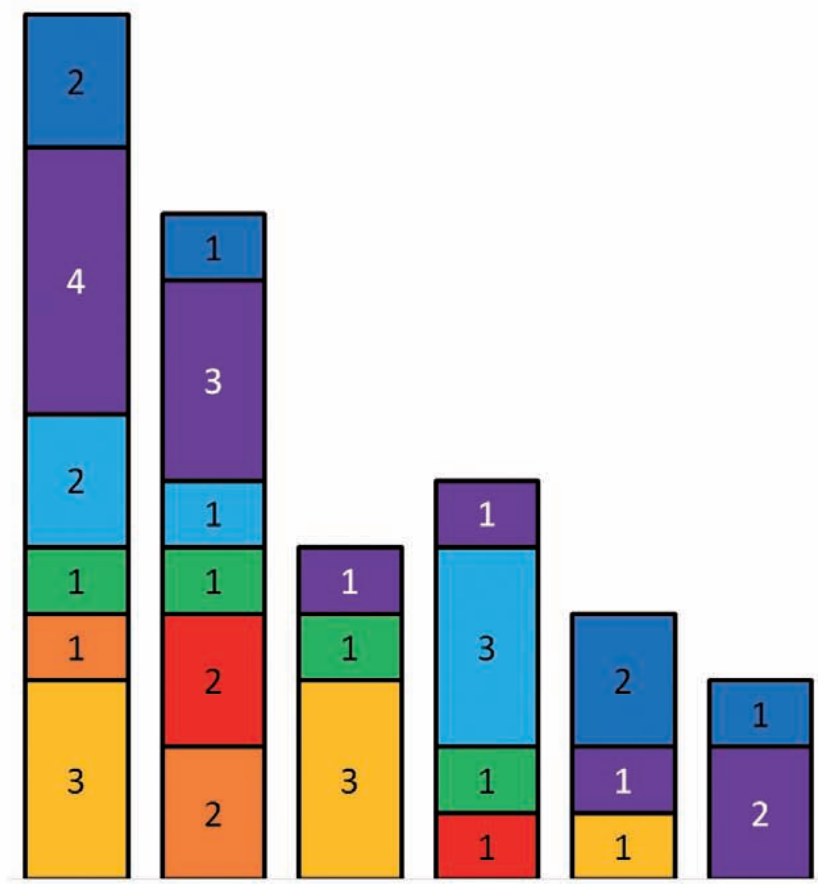

$2 B(5)$

$1 \mathrm{~B}(5)$

$2 \mathrm{D}(3)$

$4 \mathrm{~B}(13)$

$1 \mathrm{~A}(16)$

$3 B(5) \quad 4 A(12) \quad 4 C(7) \quad 4 D(8)$

Ryc. 7. Występowanie wybranych kategorii funkcjonalnych przedmiotów inwentarza w poszczególnych grupach grobów wydzielonych za pomocą analizy skupień (w nawiasach podano ilość zespołów grobowych z danym elementem)

Fig. 7. The presence of chosen functional categories of grave goods in respective groups of graves, separated by the cluster analysis (the number of burial complexes with a given element is given in brackets)

Na sąsiedniej stronie:

Ryc. 8. Analiza korespondencji zespołów grobowych (oznakowane sygnaturami oznaczającymi przynależność danego zespołu do określonej grupy wydzielonej za pomocą analizy skupień) i badanych cechy obrządku pogrzebowego (oznakowane „krzyżykami” i cyframi oznaczającymi poszczególne cechy - numeracja wg aneksu nr 2). Cyframi rzymskimi od I do VI oznaczono klasy grobów (por. tabela 3), linią przerywaną - ich granice Fig. 8. Correspondence analysis of burial complexes (marked with signatures standing for affiliation of a given complex to a specific group distinguished by cluster analysis) and the examined characteristics of funeral rite (marked with „crosses" and numerals standing for particular characteristics - numbers according to Appendix No. 2). The classes of graves have been marked with Roman numerals from I to VI (cf. Table 3), their boundaries - with the dotted line 


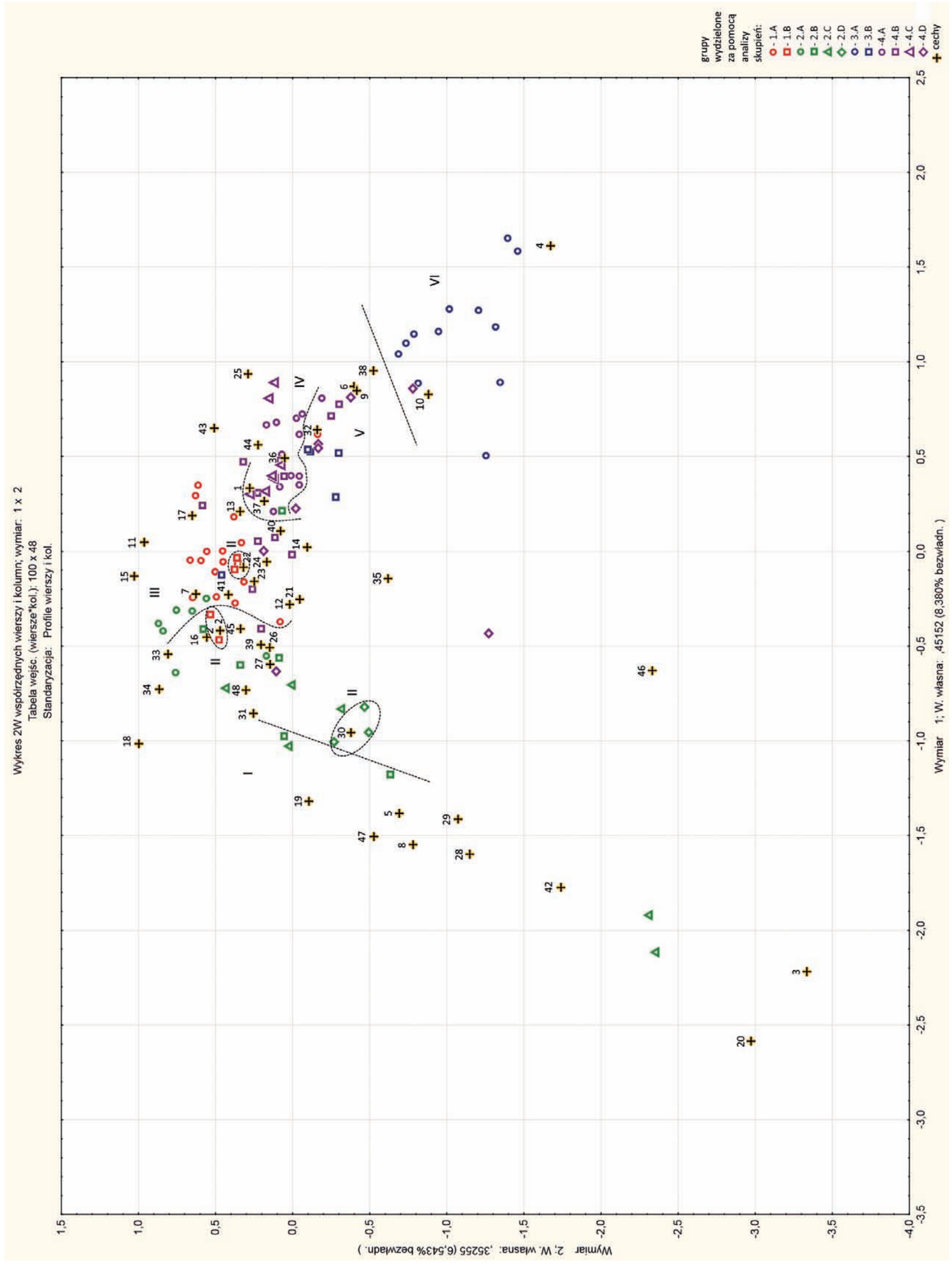


kategorii przedmiotów inwentarza, podczas gdy dla klasy V charakterystyczne są zespoły wyposażone w pojedyncze typy zabytków. Podsumowując, do klasy III zaliczonych zostało siedem zespołów, do klasy IV - cztery, a do klasy V - dwa.

Pozostałe groby zlokalizowane poza ich głównymi zgrupowaniami (grupa/klasa) wyznaczonymi za pomocą analizy skupień podzielić można na dwie grupy. Pierwszą z nich stanowią te zespoły, które analiza korespondencji umieściła poza ich głównymi skupiskami w sposób przypadkowy (najczęściej w wyniku ich wyrabowania), drugą - te pochówki, które należy łączyć z innymi zbiorami niż wykazały to wcześniej przeprowadzone analizy. Podział grobów zachodniopodolskiej grupy RSK na klasy, z uwzględnieniem powyższych uwag poczynionych $\mathrm{w}$ trakcie analizy tablicy korespondencji, przedstawiono $\mathrm{w}$ tabeli $\mathrm{nr} 4$. Wydzielone w ten sposób zbiory staną się podstawą rekonstrukcji struktury społecznej badanej populacji.

Nie mniej ważna dla weryfikacji stworzonej w oparciu o analizę skupień klasyfikacji grobów zachodniopodolskiej grupy RSK jest inna obserwacja poczyniona $\mathrm{w}$ trakcie interpretacji tablicy korespondencji. Mianowicie graficzne przedstawienie wyników analizy korespondencji badanych cech obrządku pogrzebowego i opisywanych za ich pomocą zespołów grobowych przyjmuje formę dość wyraźnego łuku na dwóch głównych osiach wykresu (ryc. 8). Według T. Madsena (2007, 20 21) paraboliczny rozkład oznaczeń jest charakte- rystyczny dla danych wykazujących ciagłość pomiędzy zmiennymi i przypadkami. Zgodnie z tą obserwacja, stopniowa i systematyczna zmiana zmiennych jest widoczna $\mathrm{w}$ kolejnych przypadkach - określone cechy obrządku pogrzebowego występują w ograniczonej liczbie grobów, a każdy grób określa limitowana ilość cech obrządku pogrzebowego. W badaniach nad periodyzacja, w przypadku których najczęściej wykorzystuje się analizę korespondencji (np. Baxter 2015, 145, fig. 9,5), taki układ danych wskazuje na chronologiczną ciagłości rozwoju analizowanych cech i zespołów grobowych. W omawianym przypadku można mówić natomiast o hierarchicznym układzie wydzielonych klas grobów: po lewej stronie osi pierwszej znajdują się zespoły klas I i II charakteryzujące się największym nakładem pracy przeznaczonym na wybudowanie grobu oraz najbogatszymi i najbardziej zróżnicowanymi inwentarzami; po przeciwnej, prawej stronie osi pierwszej znalazły się z kolei groby klas V i VI o najuboższych inwentarzach i konstrukcjach grobowych (oraz nasypach w przypadku klasy V) charakteryzujących się najmniejszymi nakładami pracy przeznaczonymi na ich wybudowanie. Mieszczące się pomiędzy wymienionymi zbiorami zespoły związane z klasami III i IV zlokalizowane są natomiast w najbliższej okolicy osi pierwszej. Groby te charakteryzują się „średnim” nakładem pracy przeznaczonym na ich wybudowanie oraz „średnim” stopniem wyposażenia.

\section{STRUKTURA SPOŁECZNA LUDNOŚCI GRUPY ZACHODNIOPODOLSKIEJ - DYSKUSJA}

Wyniki dotychczasowych badań pozwoliły na wydzielenie sześciu klas grobów zachodniopodolskiej grupy RSK. Niezwykle ważne jest to, że stworzona klasyfikacja wykazuje strukturę, którą można określić mianem hierarchicznej - zespoły grobowe zgrupowane $\mathrm{w}$ ramach kolejnej $\mathrm{z}$ wydzielonych klas (tabela 4) charakteryzują się w stosunku do poprzedniej coraz mniejszym nakładem pracy przeznaczonym na wybudowanie grobu i organizację ceremonii pogrzebowej, zaś umieszczane w nich inwentarze są coraz uboższe (zarówno w sensie ilościowym, jak i jakościowym). Nie mniej ważne dla badań nad podejmowaną w niniejszej publikacji problematyką jest obserwacja, zgodnie z którą wszystkie wydzielone zbiory grobów posiadają cechy pozwalające na uznanie ich za miejsca pochów- ku zmarłych zajmujących różne miejsca w hierarchii społecznej badanej populacji. Celem tej części pracy będzie dokonanie interpretacji (przypisanie do określonej warstwy społecznej) wydzielonych klas grobów.

Jednym z najważniejszych źródeł dla rekonstrukcji społecznej Scytów i innych zbliżonych do nich plemion, poza materiałem archeologicznym, są źródła pisane (np. Herodot, Pseudo-Hipokrates, Lukian). Należy przy tym zaznaczyć, że zawarte w nich uwagi nie odnoszą się w sposób bezpośredni do analizowanego obszaru, ale dotyczą one strefy stepu pontyjskiego. Nie bez znaczenia jest również fakt, iż najważniejszy utwór opisujący Scytów, jakim są D zieje Herodota, odnosi się do połowy Vw. p.n.e. (Ivantchik 2011, 79), a pozostałe źródła pisa- 
ne dotyczą okresów jeszcze późniejszych (Kubczak 1978, 67). Powracając do kwestii zróżnicowania społecznego Scytów w oparciu o przekazy autorów antycznych, najczęściej sprowadzano go do trójstopniowego podziału. Zgodnie z nim w jej obrębie wydzielano takie warstwy jak ród królewski (elity królewskie), arystokrację i ludność szeregową (tzw. „ośmionodzy”-Lukian, Toksaris... 1; por. Kubczak 1978, 70). Jednocześnie źródła pisane wskazują na to, że zróżnicowanie społeczne Scytów, a zwłaszcza ich elit (por. np. Kubczak 1987, 72), było bardziej heterogoniczne, niż mogłoby się to wydawać w świetle wyżej przedstawionego podziału. Poza wyżej wymienionymi trzema warstwami społecznymi skupiającymi członków wolnej, pełnoprawnej ludności, przekazy antyczne wskazują również na obecność w społeczeństwie scytyjskim grup o niepełnych prawach (ludność częściowo zależna) oraz niewolników. W przypadku tej ostatniej grupy społecznej, w oparciu D zieje Herodota (IV, 2), wskazuje się na jej przydomowy charakter (niewolnicy domowi; por. Gavriljuk 2003, 80-81).

Źródła pisane wykorzystywane były na szeroką skalę przede wszystkim przy opisywaniu zróżnicowania społecznego scytyjskich populacji ze strefy stepu pontyjskiego w oparciu o znaleziska archeologiczne (znaleziska grobowe). Należy jednak zaznaczyć, że w większości przypadków były one traktowane wybiórczo dla potwierdzenia różnych stawianych przez badaczy hipotez na temat struktury społecznej Scytów. Dlatego też nie powinien budzić zdziwienia fakt, iż pomimo dużej liczby prac poruszających kwestię zróżnicowania społecznego Scytów w oparciu o konfrontację źródeł pisanych z wynikami badań archeologicznych, trudno jest mówić o wypracowaniu przez badaczy jej spójnego obrazu (przegląd najważniejszej literatury i stawianych w niej hipotez - np. Kubczak 1978, 69-75; Vasûtin et al. 2005, 28-39; Bujnov, Okatenko 2013, 123-127). Nie mniej jednak, pomimo istniejących różnic $\mathrm{w}$ zdaniach na temat struktury społecznej ludności scytyjskiej najczęściej starano się ją sprowadzić do trzech głównych, wydzielanych w oparciu o źródła pisane, warstw społecznych - elity królewskiej (władca i członkowie jego rodu), arystokracji i ludności szeregowej. Dodatkowo w obrębie każdej z tych warstw, ze względu na różnice w stosowanym obrzędzie pogrzebowym (głównie wielkość konstrukcji grobowych i nasypu kurhanowego) i wyposażeniu grobowym, wyróżniano węższe grupy (zróżnicowanie arystokracji - por. np. Romaško, Skoryj 2009, 87-91, tam też dalsza literatura; zróżnicowanie ludności szeregowej Bunâtân 1985). Osobną kategorię społeczną stanowiła ludność zależna - niewolnicy (Il'inskaâ 1966, 166-167, 170-171).

Przy badaniu stratyfikacji społecznej ludności zachodniopodolskiej grupy RSK należy przede wszystkim rozpatrzyć ją na tle innych, współczesnych jej ugrupowań scytyjskich (o „scytyjskim” modelu kulturowym). Według badaczy zajmujących się kwestią zróżnicowania społecznego tych populacji z różnych obszarów ich funkcjonowania (Środkowe Podnieprze - Bojko 1986; 1987; 1991; 1994; Moruženko 1991; Šul'ženko 1987a; 1987b; Północny Kaukaz - Galanina 1994, 77-78) różnice widoczne w zakresie obrzędowosci pogrzebowej i wyposażeniu pochówków pozostawionych przez te społeczności jednoznacznie wskazują na ich rozwarstwienie społeczne. Jego najważniejszym przejawem jest możliwość wydzielenia wśród grobów związanych $\mathrm{z}$ omawianymi populacjami zespołów stanowiących miejsca pochówku przedstawicieli różnych grup (warstw) społecznych. Członkowie tych warstw (i grup) różnili się między sobą zajmowaną rangą (statusem), pełnioną funkcją oraz zamożnością (majątkiem). Naukowcy zajmujący się problematyką zróżnicowania społecznego ludności okresu wczesnoscytyjskiego, w zależności od stworzonej klasyfikacji i jej podstaw oraz badanego regionu, wydzielają dwie lub trzy główne warstwy społeczne. Warstwy te nie sa jednolite i charakteryzują się w wielu przypadkach wewnętrznym zróżnicowaniem.

Zgodnie z istniejącymi w literaturze hipotezami najwyższe miejsce w hierarchii społecznej ludności okresu wczesnoscytyjskiego zajmowali przedstawiciele wyższych sfer (elit). Najczęściej w obrębie warstwy tej wydzielane są dwie grupy - wojskowe wyższe sfery oraz arystokracja, w tym tzw. ,,jeździecka" (Bojko 1991, 165; Moruženko 1991, 163). Dodatkowo część badaczy wśród grobów członków wyższych sfer próbuje zidentyfikować również grupę pochówków wodzów plemiennych (np. Skoryj 1990, 69, 72). Nieco inaczej wygląda natomiast klasyfikacja elit wczesnoscytyjskich społeczności z obszaru Północnego Kaukazu. W ich przypadku przyjmuje się, że wojskowa arystokracja podporządkowana była lokalnym władcom (,królom”) i członkom ich rodzin (Galanina 1994, 78).

Drugi poziom w hierarchii społecznej zajmuja przedstawiciele warstwy średniej czy też ludności 
szeregowej. W jej obrębie wyróżniane są następujące grupy socjalne: wojownicy należący do najzamożniejszej części ludności szeregowej (Šul'ženko $1987 \mathrm{a}, 145)^{6}$, rolnicy i osoby związane $\mathrm{z}$ handlem (Bojko 1987, 177-178; 1994, 35) oraz prości rolnicy-hodowcy bydła i rzemieślnicy. Członkowie dwóch ostatnich grup społecznych, w zależności od klasyfikacji, włączani są albo do ludności szeregowej niskiej rangii (Moruženko 1991, 163), albo do warstw niższych (Bojko 1987, 177; 1991, 164-165; 1994, 34-35).

Najniższą pozycję w społecznej hierarchii zajmowała z kolei niezbyt liczna ludność zależna - najczęściej widziano w niej niewolników domowych (Bojko 1986, 36). Niekiedy na pograniczu między niewolnikami a pełnoprawnymi członkami społeczeństwa umieszczana jest warstwa częściowo zależnej ludności o ograniczonych prawach (Bojko 1986). Inną cechą wspólną dla leśnostepowych społeczności okresu wczesnoscytyjskiego (i nie tylko) jest brak osobnej klasy kapłanów czy też wróżbitów (Bojko 1987, 178-179; Bujnov, Okatenko 2013, 130) 7 .

Podsumowując obserwacje na temat zróżnicowania społecznego Scytów i ludów o pokrewnej kulturze, należy podkreślić heterogeniczność tych społeczności. Jej zasadniczym przejawem jest istnienie $\mathrm{w}$ ich obrębie różnych grup społecznych tworzących dwie-trzy główne warstwy - arystokrację (włącznie z elitami królewskimi, które niekiedy wydzielane sa jako osobna warstwa społeczna), warstwy średnie (ludność szeregowa) oraz warstwy niższe („,biedota” i ludność zależna o ograniczonych prawach). Wydaje się, że taki podział należy przyjać również dla zachodniopodolskiej grupy RSK. Poza przesłankami wynikającymi z przynależności tego ugrupowania do masywu kultur scytyjskich (o „scytyjskim” modelu kulturowym), o możliwości wydzielenia w badanym społeczeństwie kilku grup i warstw społecznych świadczą źródła funeralne. W toku ich analizy wydzielono bowiem kilka uszeregowanych hierarchicznie zbiorów (klas) gro-

6 Część badaczy (Bojko 1991, 164-165; Moruženko 1991, 163) wydziela tę grupę jako osobną warstwę społeczną, inni (Bojko 1987, 178) z kolei włączają wszystkich wojowników do wyższych warstw społecznych.

7 Zdaniem niektórych badaczy (np. Bojko 1987, 178179) prawo do odprawiania religijnych obrzędów i różnych działań kultowych było skupione w rękach przedstawicieli wyższych sfer, a zwłaszcza wojskowej arystokracji. bów, które można traktować jako miejsca pochówku przedstawicieli różnych grup społecznych.

Niewątpliwie najwyższe miejsce w hierarchii społecznej ludności zachodniopodolskiej grupy RSK, podobnie jak ma to miejsce w przypadku innych populacji wczesnoscytyjskich ze strefy lasostepu, zajmowały warstwy wyższe (elity/arystokracja). W literaturze poświęconej problematyce wyróżniania grobów arystokracji z różnych faz okresu scytyjskiego z warstwą tą w pierwszej kolejności łączone są zespoły o największych konstrukcjach grobowych i nadgrobowych z najbogatszymi i najbardziej zróżnicowanymi inwentarzami (np. Skoryj 1990, 70-73, 106-111; Galanina 1994, 76; Romaško, Skoryj 2009, 89; Ivantchik 2011, 79-83). W prezentowanej w niniejszej publikacji klasyfikacji grobów ludności zachodniopodolskiej grupy RSK cechy te posiadają zespoły zgrupowane $\mathrm{w}$ ramach klasy I oraz $\mathrm{w}$ mniejszym stopniu pochówki związane z klasą II. Zwraca uwagę fakt, iż wyłącznie zespoły związane z tym klasami (groby grup 2.C i 2.B) zakładane były w najbardziej złożonych drewniano-kamiennych grobowcach z dromosami typów 11 i 12 (tabela 4). Nie mniej charakterystyczne dla grobów związanych z obiema klasami jest również ich bogate i bardzo bogate wyposażenie z pierwszorzędną rolą zestawów broni zaczepnej, uzupełnionej o pancerze i/lub uprząż końską w grobach męskich. W tym miejscu należy odnotować, że spośród 23 zespołów grobowych o takim składzie inwentarzy $18(78,3 \%)$ to groby związane właśnie z klasami I i II. Obserwacja ta dobitnie przemawia za wojskowym charakterem „zachodniopodolskich” elit, na co już wielokrotnie zwracano uwage (por. zagadnienia wstępne). W nielicznych grobach kobiecych (głównie o układzie kobieta + osoba/osoby o nieokreślonej płci Szutnìvcy, k. 1, p. 1 i Teklìvka, k. 3) pierwszoplanową rolę $\mathrm{w}$ wyposażeniu grobowym odgrywają natomiast kilkuelementowe zestawy ozdób uzupełnione m.in. o brązowe zwierciadła. Nie mniej charakterystycznym elementem wyposażenia grobowego, koncentrującym się wyłącznie w grobach związanych z klasą I i II, są związane z różnymi działaniami rytualnymi i kultowymi brązowe noże ofiarne i elementy wozów ceremonialnych. Poza nimi wyłącznie $\mathrm{w}$ grobach obu analizowanych klas spotykane są także naczynia brązowe i broń obuchowa. W zespołach związanych z tymi klasami odnotowano również największą koncentrację importów z różnych kierunków, przedmiotów 
wykonanych z drogocennych surowców oraz elementów uprzęży i uzbrojenia ochronnego.

Wśród innych funkcjonujących w literaturze wyznaczników grobów wyższych sfer wymieniane jest również takie kryterium jak obecność w grobie towarzyszących pochówków ludzkich i/lub końskich. Wśród grobów zachodniopodolskiej grupy RSK, które w oparciu o ich cechy wielkościowe, stopień złożenia konstrukcji grobowych oraz bogactwo inwentarza zostały uznane za miejsca pochówku przedstawicieli lokalnych wyższych sfer, spotykane są tylko dodatkowe pochówki ludzkie. Brak jest natomiast w nich towarzyszących pochówków końskich, co jest cechą specyficzną tego ugrupowania kulturowego (por. Smirnova 2004, 149), aczkolwiek należy zaznaczyć, że ten element obrządku pogrzebowego jest bardzo rzadko reprezentowany także $\mathrm{w}$ innych wczesnoscytyjskich ugrupowaniach kulturowych strefy lasostepu pontyjskiego (Kovpanenko et al. 1989, 36).

Jak już wcześniej zaznaczono, arystokracja scytyjska (w tym również ta z okresu wczesnoscytyjskiego) wykazywała się znacznym zróżnicowaniem. Na heterogoniczność tej warstwy społecznej wskazują również materiały zachodniopodolskiej grupy RSK. Wewnętrzne zróżnicowanie badanych wyższych sfer ujawnia się przede wszystkim w obecności dwóch różnych zbiorów (klas) grobów, które na podstawie wyżej przedstawionych przesłanek można łączyć z tą warstwą społeczną. Podstawowymi różnicami pomiędzy tymi klasami są wysokość i średnica nasypów kurhanowych oraz wielkość i złożoność konstrukcji grobowych (tabela 4). Pod tym względem wyższe miejsce w hierarchii badanych elit zajmuja zmarli pochowani w najbardziej okazałych grobowcach typów 11 i 12 zgrupowanych w ramach klasy I. Jeżeli chodzi o interpretację tej grupy społecznej, to jak wskazują na to niektórzy badacze, w tym autor niniejszej publikacji, groby tej klasy mogły mieścić pochówki członków wojskowej arystokracji najwyższego poziomu - wojskowych przywódców („wodzów”) i naczelników (Gucal 2012, 154-155; Burghardt 2015, 160). Niewykluczone, że właśnie w tej grupie grobów należałoby widzieć miejsca pochówków Herodotowych nomarchów - naczelników powiatów (nomów) będących zarazem dowódcami plemiennego (pochodzącego z określonego powiatu) pospolitego ruszenia (Herodot
IV, 64; por. Kubczak 1978, 72) ${ }^{8}$. Niższą pozycję w hierarchii wyższych sfer badanego społeczeństwa zajmowali z kolei zmarli chowani w grobach klasy II. Zespoły te w porównaniu z grobami klasy I charakteryzują mniejsze wielkości nasypów i konstrukcji grobowych oraz większe zróżnicowanie formalne tych ostatnich - poza pojedynczymi grobowcami typu $11 \mathrm{w}$ klasie tej spotykane są również mniej lub bardziej złożone grobowce słupowe typów 5, 8-10, a także najprostsze konstrukcje typów 1-3 (tabela 4). Również i w przypadku tej klasy grobów można w nich widzieć miejsca spoczynku członków różnych mniejszych grup w obrębie arystokracji. Niewattpliwie w niektórych z tych zespołów, zwłaszcza tych zawierających elementy uprzęży (głównie groby grup 2.B i 2.C), widzieć można pochówki arystokracji ,jeździeckiej”. Dodatkowo obecność w części z nich (przeważnie groby grupy 2.D) większych zestawów uzbrojenia, w skład którego poza strzałami (i niekiedy włócznią) wchodziły także broń obuchowa i sieczna oraz pancerze, wskazuje na to, że spośród tej warstwy rekrutowała się znaczna część wyspecjalizowanych wojowników, tzw. „drużynników” (por. Bessonova 1998; Burghardt 2015, 159-160).

Niewykluczone, że z arystokracją łączyć należy również pewną ilość grobów związanej z klasą III grupy 1.A (Dolinâny, k. 3 i 4; Perebykivci, k. 5; Teklìvka, k. 2). Na ich związek z tą właśnie warstwą społeczną wskazują liczne podobieństwa do grobów klasy II, widoczne przede wszystkim na poziomie konstrukcji grobowych (powierzchnia rzędu ok. 13-31 m² i wyłączna obecność grobowców słupowych typów 5 i 7). Również inne cechy obrządku pogrzebowego (towarzyszące pochówki ludzkie; obecność w części inwentarzy takich przedmiotów jak uprząż, broń sieczna i elementy uzbrojenia ochronnego) wykazują większe zbieżności z grobami tej klasy niż z pozostałymi zespołami grobowymi grupy 1.A. Należy również podkreślić, że na tablicy korespondencji (ryc. 8) omawiane zespoły zlokalizowane są w pobliżu skupiska grobów klasy II, które jak już to wskazano traktowane są

$8 \mathrm{Na}$ taką interpretację tych zespołów grobowych wskazywać może ich lokalizacja w obrębie największych zagęszczeń stanowisk zachodniopodolskiej grupy RSK (por. Eberts 2012, fig. 1). 
jako miejsca spoczynku przedstawicieli wyższych warstw badanego społeczeństwa.

Łącznie do grupy grobów wyższych sfer zaliczono 27 zespołów, aczkolwiek ich pierwotna liczba była zapewne znacznie większa. Spośród zespołów, które z racji niewystarczającej ilości danych zostały pominięte $\mathrm{w}$ analizach, cechy analogiczne do wyżej opisanych grobów ,zachodniopodolskich" elit posiada co najmniej sześć - kurhan nr C z Nowosiółki Grzymałowskiej (w inwentarzu m.in. czekan i uprząż) (Sulimirski 1936, 84), kurhany nr 4 z Perebykivci i nr 2 z miejscowości Šutnìvcì (w obu grobowce typu 7 o powierzchniach wynoszaccych ponad $20 \mathrm{~m}^{2}$ ) (Smirnova 1979, 53-55; Gucal and Gucal 2009), kurhan nr 1 z miejscowości Serwantyńce (nasyp o wysokości $2 \mathrm{~m}$, w inwentarzu m.in. fragmenty pancerza) (Sulimirski 1936, 95), zniszczony kurhan z Sokirnic (w inwentarzu sztylet) (Gucal 2004, 44) oraz częściowo publikowany kurhan nr 1, tzw. Rozbita Mogila z miejscowości Kociubińczyki.

Szczególnie interesujący jest ostatni z wyżej wymienionych zespołów grobowych. Na podstawie nielicznych wzmianek w literaturze (Bandrìvs'kij M. 2009c, 113-; 2010a; 149, 151, 156, fig. 6, 8, 4, 7; 2014, 323, 345, 347, 526-529, 532, 533, 545) $)^{9}$ zespół ten bowiem można określić jako najbardziej wyróżniający się spośród wszystkich znanych zespołów zachodniopodolskiej grupy RSK. Jego najbardziej charakterystyczną cechą jest znaczna wielkość nasypu kurhanowego (92 m średnicy i 8-10 m - stan na 1977 r. - wysokości), który dodatkowo otoczony był systemem wałów. Pod nasypem tym znajdował się grobowiec mieszczący szczątki trojga osób - mężczyzny, kobiety i dziewczynki w wieku 5-7 lat. Zmarłym towarzyszyło niezwykle bogate wyposażenie grobowe, w skład którego wchodziły m.in. złota blaszka-aplikacja kołczanu lub nakrycia głowy, liczne ozdoby wykonane ze złota, srebra i górskiego kryształu oraz brązowe zwierciadło. Tak duża ilość przedmiotów wykonanych $\mathrm{z}$ drogocennych metali nie znajduje żadnej analogii wśród wszystkich znanych zespołów grobowych zachodniopodolskiej grupy RSK. Niestety brak jest danych na temat typu konstrukcji grobowej i jego wielkości. Autor badań zamieszcza tylko informację o tym, że zmarli umieszczeni byli w złożonym drewniano-kamiennym grobowcu analogicznym

9 http://www.lvivpost.net/lvivnews/n/8508 (dostęp 20 grudnia 2015 r.). do konstrukcji grobowych znanych z „elitarnych” kurhanów krasnoznamenskiego cmentarzyska z terenów Północnego Kaukazu (Bandrìvs'kij 2014, $545)^{10}$.

Jeżeli chodzi o interpretację opisywanego zespołu, to zdaniem M. Bandrìvs'kiego (2009c) zespół ten pełnił dwojaką funkcję. Po pierwsze mieścił on pochówek członków rodu rządzącego i arystokracji, po drugie - stanowił on część większego kompleksu kultowego poświęconego Aresowi. Wydaje się, że w świetle dostępnych informacji można domniemywać, iż opisywany zespół pierwotnie stanowił miejsce pochówku zmarłych zajmujących bardzo wysoką pozycję społeczną. Porównując nakład pracy przeznaczony na jego wybudowanie (a zwłaszcza wzniesienie samego nasypu kurhanowego) oraz bogactwo złożonego w nim inwentarza, można stwierdzić, że jest on nieporównywalny z żadnym z zespołów przeanalizowanych $\mathrm{w}$ niniejszej pracy. Obserwacja ta pozwala przypuścić, że pochowane w nim osoby zajmowały najwyższe miejsce w hierarchii społeczności zachodniopodolskiej grupy RSK. Jest bardzo możliwym, że zespół ten stanowił miejsce spoczynku lokalnego władcy ${ }^{11}$. Jednocześnie nie można wykluczyć, że obiekt ten pełnił jakieś funkcje kultowe ${ }^{12}$, aczkolwiek trudno jest tu mówić o kulcie Aresa, jak chce tego M. Bandrìvs'kij.

Jak wykazano w trakcie wyżej przeprowadzonych analiz, środkowe miejsce w stworzonym systemie klasyfikacji grobów zachodniopodolskiej grupy RSK zajmują zespoły związane z klasami III i IV. Cechy metryczne nasypów i konstrukcji grobowych, które można określić jako małe (klasa IV) lub średniej wielkości (klasa III), ich złożoność, a także „średni” stopień wyposażenia grobowego (tabela 4), pozwalają widzieć w zmarłych pochowanych w grobach obu tych klas przedstawicieli warstwy średniej (ludności szeregowej). Warstwa

10 Zdaniem badaczy w największym z kurhanów z tego cmentarzyska pochowano władcę, zaś w pozostałych - członków wojskowej arystokracji (Petrenko 2006).

11 Poza monumentalnością jego konstrukcji oraz przepychem bogactwa o takiej interpretacji tego zespołu może świadczyć również jego lokalizacja niemalże w samym środku ekumeny ludności omawianego ugrupowania kulturowego (por. Eberts 2012, fig. 1).

12 Pełnienie kultowej (rytualnej) funkcji przez grobowce „scytyjskich” władców poświadczone jest m.in. przez znaleziska z wyżej wspomnianych kurhanów z krasnoznamenskiego cmentarzyska (Petrenko 2006). 
ta stanowiła najliczniejszą część scytyjskiego społeczeństwa (włącznie ze społecznościami o „scytyjskim" modelu kulturowym) i, podobnie jak ma to miejsce w przypadku warstw wyższych, nie była ona jednolitym monolitem. Jej członkowie, jak wskazują na to znaleziska archeologiczne (zespoły grobowe), różnili się między sobą statusem (ranga), pełnioną funkcją oraz zamożnością (np. Šul'ženko 1987a, 145; Bunâtân 1985; Bojko 1987, 177-178; 1991, 164-165; 1994, 35; Moruženko 1991, 163; Bujnov, Okatenko 2013, 131). Również i w przypadku zachodniopodolskiej grupy RSK zespoły grobowe wiązane z ludnością szeregową wykazują wewnętrzne zróżnicowanie, czego przejawem jest wyróżnienie dwóch klas i kilku mniejszych grup grobów, które można łączyć z tą warstwą społeczną.

Bezsprzecznie wyższe miejsce $\mathrm{w}$ hierarchii warstwy średniej badanej społeczności zajmuja zmarli pochowani w grobach klasy III. Niektóre cechy obrządku pogrzebowego widoczne w zespołach grobowych tej klasy (wielkość konstrukcji grobowych i stopień ich złożoności, stopień „bogactwa” wyposażenia grobowego połączony $\mathrm{z}$ obecnością w części z nich wyróżniających się kategorii przedmiotów inwentarza; por. tabela 4) pozwalają przypuścić, że mogły one mieścić pochówki bogatych i wyróżniających się członków tej warstwy społecznej. Szczególnie charakterystyczne dla zespołów grobowych omawianej klasy są pochówki męskie wyposażone $\mathrm{w}$ różne elementy uzbrojenia (i ich zestawy). Obecność tego typu przedmiotów w grobie podkreśla bowiem rolę zmarłego przede wszystkim jako wojownika ${ }^{13}$. Z miejscami pochówku bogatszych członków ludności szeregowej, poza zespołami klasy III, łączyć można również pewną część grobów klasy IV. Zespoły te na tle innych grobów związanych z tą klasą wyróżniają się bogactwem złożonego w nich inwentarza (Bratyszów, k. 4; Malinìvcì, k. 4; Serwantyńce, k. 3, poch. 1; Sokìlec, k. 3) lub wielkością konstrukcji grobowej (Sokìlec, k. 4). Dodatkowo wykaz zespołów gro-

13 Niewykluczone, że w części przypadków wojownicy pochowani w grobach klasy III należeli do grupy „drużynników”, przy czym uwaga ta odnosi się wyłącznie do zespołów grobowych wyposażonych w elementy uprzęży i/lub pancerze (Iwachnowce, k. 2, p. 1; Spasìvka, k. 1; Šutnìvcì; por. Burghardt 2015, 160, 161). Obserwacja ta pozostaje W zgodzie z wcześniejszymi spostrzeżeniami autora odnośnie do heterogeniczności tej grupy społecznej i jej związku z różnymi warstwami społecznymi (Burghardt 2015, 160). bowych związanych z pochówkami bogatszych członków warstwy średniej można uzupełnić o pojedynczy zespół klasy V z Mińkowic (pochówek nr 1). Co prawda pochówek ten złożony był w niewielkiej jamie o wymiarach zbliżonych do grobów klasy IV, zaś jego wyposażenie ograniczało się zaledwie do dwóch grocików strzał i lepionych ręcznie garnka i misy, to jednakże obecne w nim ślady rabunku pozwalają przypuścić, że pierwotnie grób ten był znacznie bogaciej wyposażony, niż zostało to uchwycone ${ }^{14}$.

Nieco inaczej wygląda kwestia pozycji społecznej zmarłych członków warstwy średniej pochowanych w zespołach klasy IV (poza wyżej wymienionymi czterema grobami). Mniejsze nakłady pracy w porównaniu $\mathrm{z}$ grobami klasy III i obecność uboższego wyposażenia grobowego (tabela 4) wskazują na to, że zmarli związani z tą klasą zajmowali niższą pozycję w obrębie warstwy średniej niż osoby pochowane w grobach klasy III. Brak innych rodzajów militariów w grobach męskich (włącznie z pochówkami podwójnymi męsko-żeńskimi) niż niewielkie zestawy grocików strzał, przy jednoczesnej nieobecności śladów rabunku tych zespołów, wskazuje na to, że pochowani w nich zmarli za życia pełnili inne funkcje niż te bezpośrednio związane $\mathrm{z}$ działalnością wojskową. Byli to zapewne rolnicy, hodowcy bydła, rzemieślnicy i być może osoby zajmujące się handlem. Analogiczną interpretację można przenieść również na część niewyrabowanych pochówków męskich (męsko-żeńskich) klasy III, w obrębie których nie ujawniono obecności żadnych elementów uzbrojenia włącznie z grocikami strzał (Malinìvcì, k. 1, p. 1; Šutnìvcì, k. 4, p. 2).

Kończąc charakterystykę szeregowej ludności zachodniopodolskiej grupy RSK, bez uwzględnienia różnic $\mathrm{w}$ statusie (randze) zmarłych $\mathrm{i}$ ich zamożności, a także pełnionych przez nich funkcji, należy zaznaczyć, że warstwa ta była najliczniejszą częścią badanej społeczności, co jest typowym zja-

14 Dodatkowym argumentem przemawiającym za związkiem złożonej w tym grobie osoby z warstwą ludności szeregowej wyższej rangi (wojownicy) jest fakt, iż pod nasypem kurhanowym znajdował się jeszcze jeden grób o peryferyjnym (pobocznym) charakterze (poch. nr 2). Prezentowane w niniejszej pracy analizy wykazały, że pochówki poboczne najczęściej współwystępują właśnie z zespołami o centralnej lokalizacji przynależącymi do klasy III lub wyższej. 
wiskiem również dla innych ugrupowań ze strefy lasostepu okresu wczesnoscytyjskiego (i nie tylko dla nich). W sumie wydzielono co najmniej 49 zespołów grobowych, które można połączyć z ludnością szeregową. Jednocześnie należy zaznaczyć, że liczba ta pierwotnie była znacznie wyższa, niż zostało to uchwycone $\mathrm{w}$ trakcie prezentowanych w niniejszej publikacji analiz. Z warstwą tą łączyć można bowiem również 14 zespołów grobowych, które ze względu niewystarczającą ilość danych nie zostały uwzględnione w powyższych badaniach, ale wykazują one pewne cechy analogiczne do grobów klas III i IV. Są to: Bermiany, k. 4; Čabanìvka, k. 1 i 9; Dupliska, k. 3; Iwachnowce, k. 3; Krugle; Kupin, k. 1; Lisičinki; Nowosiółka Grzymałowska, k. B; Postołówka; Spasivka, k. 4, p. 1; Tarasovka, k. 2 i 4; Zawadincy, k. 1 (Sulimirski 1936, 66-67, 71, 74, 80-81, 82, 92-93; 99; Smirnova 1967, 229230; 1979, 53-55; Gucal et al. 2012, 142, 143).

Jedno z najniższych miejsc w stworzonej klasyfikacji grobów zachodniopodolskiej grupy RSK zajmuja zespoły grobowe klasy V. Groby te pod względem swoich cech metrycznych (wysokość i średnica nasypów kurhanowych, powierzchnia konstrukcji grobowych) nawiązują do zespołów klasy IV, ale w porównaniu z nimi zakładane są na ogół w prostszych typach konstrukcji grobowych, zaś ich inwentarze są znacznie uboższe (naczynia lepione ręcznie i/lub pojedyncze rodzaje ozdób; por. tabela 4). Niskie nakłady pracy przeznaczone na wybudowanie grobu i nakrycie go nasypem oraz ubogi charakter wyposażenia grobowego pozwalają przypuścić, że zmarli chowani w zespołach grobowych tej klasy zajmowali jedno z najniższych miejsc w strukturze społecznej populacji zachodniopodolskiej grupy RSK - zapewne były to groby najuboższej ludności (tzw. „,biedoty”). Łącznie wydzielono dziesięć zespołów, w przypadku których można pokusić się o przynależność zmarłych do tej warstwy społecznej ${ }^{15}$.

Ostatnie, najniższe miejsce w stworzonej klasyfikacji zespołów grobowych badanej społeczności zajmują zespoły grobowe o pobocznym charakterze klasy VI. W pierwszej kolejności należy zaznaczyć, iż w świetle wielokrotnie już przytaczanej koncepcji o nakładzie pracy przeznaczonej na wy-

15 Wykaz ten uzupełniają dwa nieuwzględnione w analizach zespoły grobowe - kurhan nr 2 z C̆abanìvi (Gucal et al. 2012, 143) oraz kurhan nr 2 z Oselivki (Mogilov 2010, 115). budowanie grobu (i organizację ceremonii pogrzebowej) jako odzwierciedleniu pozycji społecznej zmarłych, zespoły o bocznym (peryferyjnym) charakterze powinny zawierać pochówki osób o niższej pozycji socjalnej niż zmarli, dla których usypano konkretny nasyp kurhanowy (Tainter 1978, 127f.; Mizoguchi 1993, 227). Spostrzeżenie to potwierdza ogólna charakterystyka zespołów grobowych klasy VI - w jej przypadku zmarłych składano w najmniejszych, a zarazem najprostszych konstrukcjach grobowych, zaś towarzyszące im inwentarze można określić jako ubogie (tabela 4). W świetle tej obserwacji można pokusić się o interpretację zmarłych pochowanych w grobach pobocznych klasy VI jako osoby pozostające w pewnej (czesściowej? całkowitej?) zależności od zmarłych złożonych w grobach o centralnej lokalizacji. Jednocześnie należy zaznaczyć, że taki sposób interpretacji grobów tej klasy jest wiarygodny, jeżeli osoby pochowane w grobach centralnych zajmuja wysokie miejsce w hierarchii społecznej (wyższe sfery i uprzywilejowana ludność szeregowa - por. np. Bojko 1987, 178). Przeprowadzona pod tym kątem analiza wykazała, że sytuacja taka zachodzi także w obrębie zachodniopodolskiej grupy RSK, przy czym w zdecydowanej większości przypadków w osobach pochowanych w głównych grobach (o centralnej lokalizacji) widzieć można przedstawicieli ludności szeregowej wyższej rangi. Tylko w dwóch kurhanach (Spasìvka, k. 9 i Šutnovcy, k. 1) pochówki poboczne klasy VI towarzyszą grobom przypisanym członkom wyższych sfer. $Z$ drugiej strony należy zaznaczyć, że relacje zachodzące pomiędzy zmarłymi pochowanymi w grobach klasy VI a osobami umieszczonymi w grobach o centralnej lokalizacji można rozpatrywać także $\mathrm{w}$ innym aspekcie niż ludność zależna (częściowo zależna?) - uprzywilejowana ludność wolna wysokiej rangi. Kluczowy jest tutaj kurhan nr 1 z miejscowości Malìnìvci mieszczący pod nasypem aż cztery równoczasowe groby, z których główny mieścił szczątki dwojga dorosłych, mężczyzny i kobiety, natomiast jeden z bocznych (nr 3) zawierał pochówek dwójki dzieci i osoby o nieokreślonej płci. W tej konkretnej sytuacji można najprawdopodobniej mówić o grobach rodziców z dziećmi, przy czym dzieci zostały pochowane w innym miejscu (osobny grób) niż ich rodzice.

Powracając do kwestii możliwości wydzielania wśród ludności zachodniopodolskiej grupy RSK ludności zależnej (niewolników domowych? - por. 
wzmianka Herodota o charakterze niewolnictwa u Scytów-D zieje, IV, 2), poza pochówkami pobocznymi (ich częścią?) należy wziąć pod uwage jeszcze jedną grupę źródeł. Zaliczają się do niej wymieniane przy okazji charakterystyki wyższych warstw społecznych tzw. towarzyszące pochówki ludzkie. W literaturze za takie przyjęto uważać pochówki podwójne i zbiorowe, w przypadku których jeden ze zmarłych (na ogół dziecko lub nastolatek) złożony jest do grobu w określony sposób - najczęściej w pozycji skurczonej na boku, w nogach głównego zmarłego lub na skraju komory grobowej, a nawet poza jej granicami. Nie mniej ważnym kryterium dla wydzielania tej grupy pochówków jest ubogie wyposażenie grobowe (a nawet jego brak w dużej części przypadków) towarzyszące złożonym w ten sposób zmarłym (por. np. Moruženko 1991, 164; Babenko 2005, 175; Kovpanenko et al. 1989, 35). Wśród materiałów zachodniopodolskiej grupy RSK kryterium to spełniają dwa groby (Dolinâny, k. 4; Zozulince, k. 1) ${ }^{16}$. Jednocześnie nie można wykluczyć, że pierwotna liczba tego typu zespołów była znacznie większa niż zostało to uchwycone. Podstawową trudnością uniemożliwiającą rozpoznanie pochówków o takim charakterze jest już wielokrotnie przytaczane wyrabowanie znacznej części grobów zachodniopodolskiej grupy RSK, a zwłaszcza tych związanych z wyższymi warstwami tego społeczeństwa. Rabunek tych grobów uniemożliwia nie tylko powiązanie konkretnych elementów wyposażenia grobowego z poszczególnymi zmarłymi, ale niejednokrotnie powoduje wymieszanie szczątków zmarłych w sposób uniemożliwiający określenie ich pierwotnej pozycji i lokalizacji w grobie.

${ }^{16} \mathrm{~W}$ tym miejscu należy zaznaczyć, że istnieje jeszcze inna możliwość interpretacji tych zespołów. Niewykluczone, że mogły być to swoistego rodzaju pochówki ofiarne (por. np. Bessonova 1992), niejako wieńczące proces grzebania głównego zmarłego. Na taką ich interpretację może wskazywać poczyniona przez G.I. Smirnovą (1979, 52) obserwacja odnośnie dwuetapowego składania zmarłych
Kończąc charakterystykę zróżnicowania społecznego ludności zachodniopodolskiej grupy RSK, należy zwrócić uwagę na jeszcze jedną kwestię, jaką jest liczebnośc osób przynależących do poszczególnych warstw społecznych. W trakcie analiz wielokrotnie podkreślano fakt, iż badaniu poddana została tylko część zespołów grobowych związanych $\mathrm{z}$ rozpatrywanym ugrupowaniem kulturowym. Jednocześnie nie we wszystkich przypadkach udało się określić ilość zmarłych złożonych w jednym grobie. Jeżeli przyjrzeć się strukturze społecznej ludności zachodniopodolskiej grupy RSK wyłącznie przez pryzmat zespołów grobowych poddanych analizie, to udział grobów związanych z poszczególnmi warstwami społecznymi kształtuje się w następujący sposób: groby wyższych sfer różnej rangi - 27 zespołów ( 5 związanych z wojskowymi przywódcami i 22 z pochówkami członków arystokracji ,jeździeckiej"); groby ludności szeregowej - 49 zespołów; pochówki „biedoty” - 10 zespołów; pochówki ludności zależnej (i częściowo zależnej) - co najmniej 14 pochówków (włącznie $\mathrm{z}$ dwoma pochówkami towarzyszącymi z grobów elit). Obraz ten ulega pewnej zmianie, jeżeli uzupełni się go o inne, wzmiankowane w tekście zespoły, które $\mathrm{z}$ różnych przyczyn nie zostaly uwzględnione $\mathrm{w}$ prezentowanych analizach (20 zespołów). W tym przypadku sytuacja wygląda następująco: groby wyższych sfer (łącznie z pojedynczym pochówkiem o charakterze „królewskim") - 33 zespoły (27,5\% ze 120 grobów); groby ludności szeregowej - 63 zespoły $(52,5 \%)$; pochówki „,biedoty” - 12 zespołów (10\%); liczba zespołów, które można łączyć z pochówkami ludności zależnej pozostaje bez zmian (10\%). w niektórych grobach podwójnych i zbiorowych. Pierwszy z nich miałby być związany z głównym pochówkiem, drugi - odbywałby się jakiś czas po głównej ceremonii pogrzebowej (spalenie głównego zmarłego razem z konstrukcją grobowa), tuż przed usypaniem nad grobem nasypu kurhanowego. 


\section{WNIOSKI}

Wnioski $\mathrm{z}$ przeprowadzonych $\mathrm{w}$ niniejszym studium badań można podzielić na odnoszące się do obrządku pogrzebowego jako odzwierciedlenia struktury społecznej badanej społeczności oraz interpretacji uzyskanych wyników. Daje się zauważyć, że w przypadku populacji zachodniopodolskiej grupy RSK, podobnie jak odnotowano to dla innych społeczności o scytyjskim modelu kulturowym, zasadnym jest traktowanie związanych z nią materiałów funeralnych (zespołów grobowych) jako podstawowego źródła do badań nad jej strukturą społeczną. Jednocześnie szczegółowe analizy stosowanego przez nia obrządku pogrzebowego potwierdziły, że podstawowym kryterium pozwalającym na określenie miejsca zajmowanego za życia przez zmarłego w badanym społeczeństwie (jego statusu) jest określenie nakładu pracy przeznaczonego na dokonanie jego pochówku. Nakład ten (straty energii) uwidacznia się w wielkości grobu (konstrukcje grobowe i nadgrobowe w postaci nasypów kurhanowych) i stopniu jego złożoności. Nie mniej ważnym kryterium pozwalającym na określenie pozycji socjalnej zmarłego jest również bogactwo złożonego z nim wyposażenia grobowego (zwłaszcza ilość kategorii przedmiotów inwentarza) - w przypadku zachodniopodolskiej grupy RSK wykazano bowiem istnienie wyraźnych korelacji pomiędzy wielkością grobu a bogactwem umieszczanego w nim wyposażenia grobowego.

Drugim istotnym wnioskiem jest wykazanie heterogeniczności struktury społecznej badanej populacji. Analiza związanych z nia grobów wyraźnie wykazała, że społeczeństwo to nie było jednolite i rozbijało się na mniejsze grupy (warstwy) różniące się między sobą rangą (statusem), funkcją i pozycją majątkową. Na poziomie źródeł archeologicznych zróżnicowanie to przejawia się z kolei w możliwości wydzielenia wśród rozpatrywanych grobów różnych ich grup (i zbiorów). Wykorzystując metody wnioskowania statystycznego (analizy skupień i korespondencji), analizowany materiał podzielono na 12 grup skupionych w ramach sześciu mniejszych klas. Niezwykle ważne jest to, że stworzona klasyfikacja wykazuje strukturę, którą można określić mianem hierarchicznej - zespoły grobowe zgrupowane $\mathrm{w}$ ramach kolejnej $\mathrm{z}$ wydzielonych klas charakteryzują się w stosunku do poprzedniej coraz mniejszym nakładem pracy przeznaczonym na wybudowanie grobu i organizację ceremonii pogrzebowej, zaś umieszczane w nich inwentarze są coraz uboższe.

W oparciu o wydzielone zbiory grobów, a także dane na temat zróżnicowania społecznego innych grup scytyjskich (o „scytyjskim” modelu kulturowym), można przyjąć kilkustopniowy podział ludności zachodniopodolskiej grupy RSK. I tak, najwyższe miejsce (nie uwzględniając hipotetycznego pochówku lokalnego władcy z tzw. Rozbitej Mogily z miejscowości Kociubińczyki) w strukturze społecznej badanej populacji zajmowali członkowie wyższych sfer (elit) w typie wojskowej arystokracji. Warstwa ta nie była jednolita i rozpadała się na przynajmniej dwie grupy społeczne - zajmujących wyższą pozycję socjalną wojskowych przywódców („wodzów” i naczelników) oraz posiadających niższą rangę członków arysokracji ,jeździeckiej”. Srodkowe miejsce w hierarchii społeczności zachodniopodolskiej grupy RSK zajmowała z kolei najliczniejsza warstwa średnia (ludność szergowa). Rówież i ta warstwa nie była jednolita i rozpadała się na co najmniej dwie mniejsze grupy społeczne. Pierwszą z nich, zajmującą uprzywilejowaną pozycję w obrębie tej warstwy, stanowili wojownicy oraz odpowiadające im statusem kobiety, drugą - pozostała ludność szeregowa, w skład której wchodzili rolnicy, hodowcy bydła, rzemieślnicy oraz być może osoby związane $\mathrm{z}$ handlem. Najniższą pozycję w obrębie pełnoprawnej, wolnej ludności zajmowała „biedota” (ludność najuboższa). Na samym dole hierarchii społecznej populacji zachodniopodolskiej grupy RSK znajdowały się natomiast osoby o ograniczonych prawach - ludność zależna (w tym niewolnicy domowi?). Członkowie tej warstwy byli chowani zarówno w osobnych grobach o pobocznym charakterze, jak również we wspólnym grobie z głównym zmarłym (przy założeniu, że nie są to pochówki ofiarne). 
STRATYFIKACJA SPOŁECZNA LUDNOŚCI ZACHODNIOPODOLSKIEJ GRUPY KULTURY WCZESNOSCYTYJSKIEJ

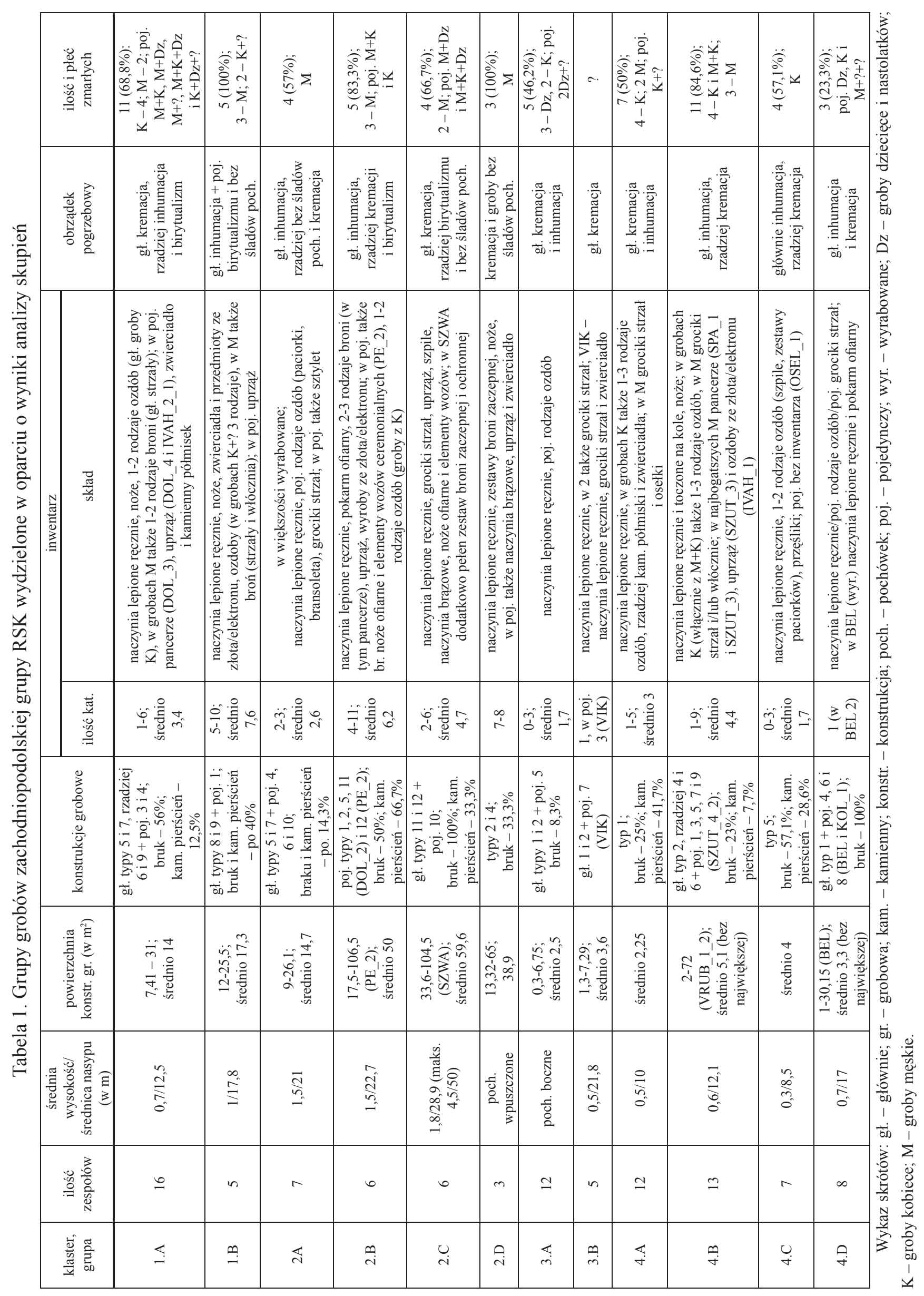


Tabela 2. Wartości współczynnika splendoru obliczone dla podstawowych kategorii funkcjonalnych przedmiotów inwentarza zachodniopodolskiej grupy RSK

\begin{tabular}{|c|c|}
\hline $\begin{array}{c}\text { Kategoria inwentarza (ilość zespołów z daną } \\
\text { kategorią) }\end{array}$ & $\begin{array}{l}\text { Wartość współczynnika } \\
\text { splendoru }\end{array}$ \\
\hline nóż (24) & 5,7 \\
\hline osełka (6) & 6,2 \\
\hline przęślik (6) & 3,7 \\
\hline grociki strzał (39) & 4,5 \\
\hline broń drzewcowa (10) & 6,3 \\
\hline broń obuchowa (6) & 8 \\
\hline broń sieczna (4) & 5,25 \\
\hline uzbrojenie ochronne (6) & 6,4 \\
\hline elementy uprzęży (12) & 6,7 \\
\hline paciorki - zestawy (19) & 4,8 \\
\hline pojedyncze paciorki (10) & 5,1 \\
\hline bransoleta (3) & 5 \\
\hline zawieszki, wisiorki, amulety itp. (3) & 5,3 \\
\hline zausznice (15) & 4,5 \\
\hline szpile (27) & 4,8 \\
\hline ozdoby - pozostałe (5) & 4,2 \\
\hline naczynia lepione ręcznie (86) & 3,7 \\
\hline naczynia toczone na kole (7) & 5,7 \\
\hline naczynia brązowe (3) & 6,7 \\
\hline kamienny półmisek (5) & 3,4 \\
\hline siarka, realgar (6) & 5,2 \\
\hline zwierciadło brązowe (13) & 5,9 \\
\hline kościane przedmioty toaletowe (5) & 5,4 \\
\hline brązowe noże ofiarne/elementy wozów (3) & 8 \\
\hline przedmioty wykonane z drogocennych metali (7) & 7,7 \\
\hline pokarm ofiarny (12) & 5 \\
\hline ciosła (2) & 9 \\
\hline importy środkowoeuropejskie (4) & 8,75 \\
\hline
\end{tabular}




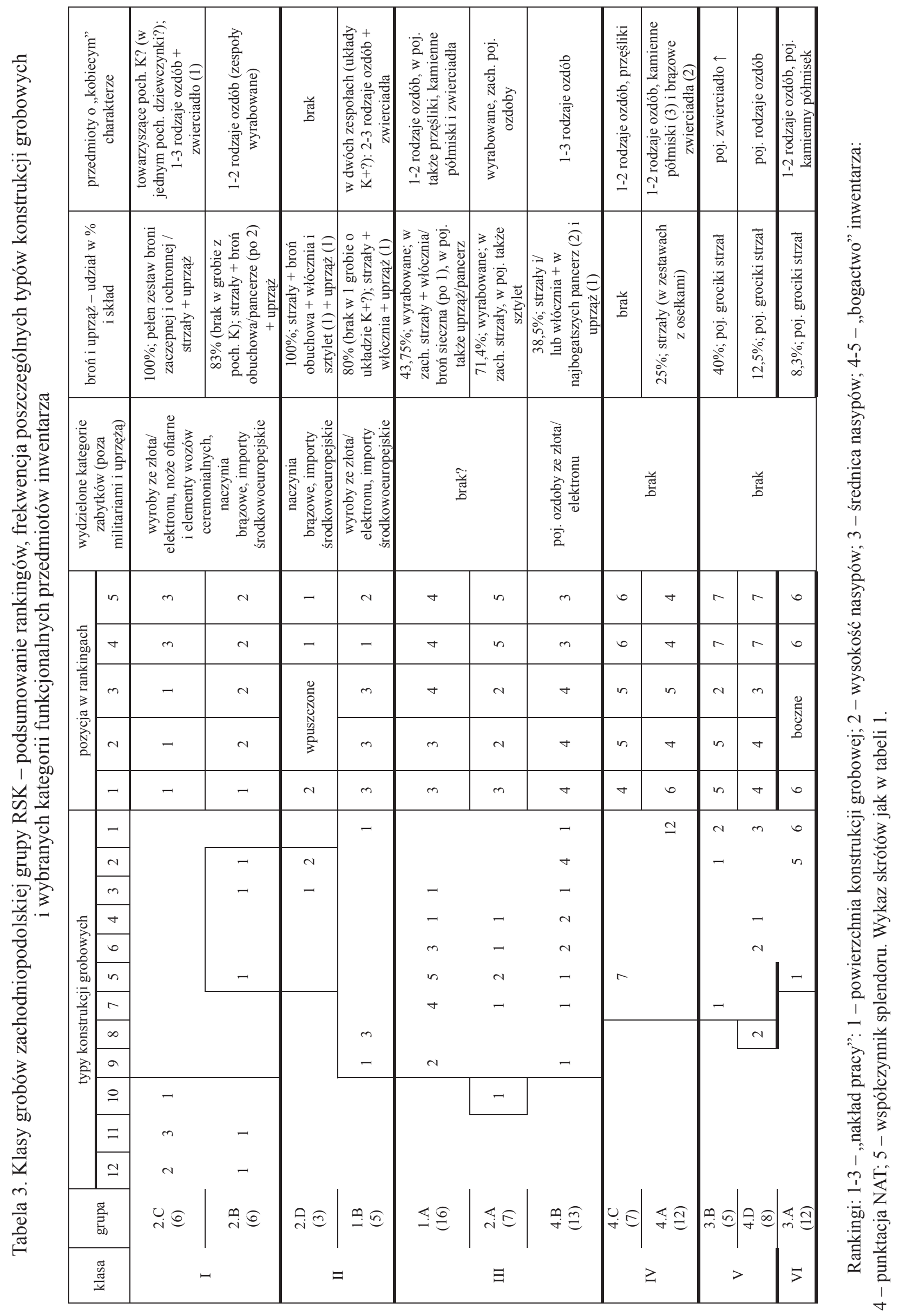




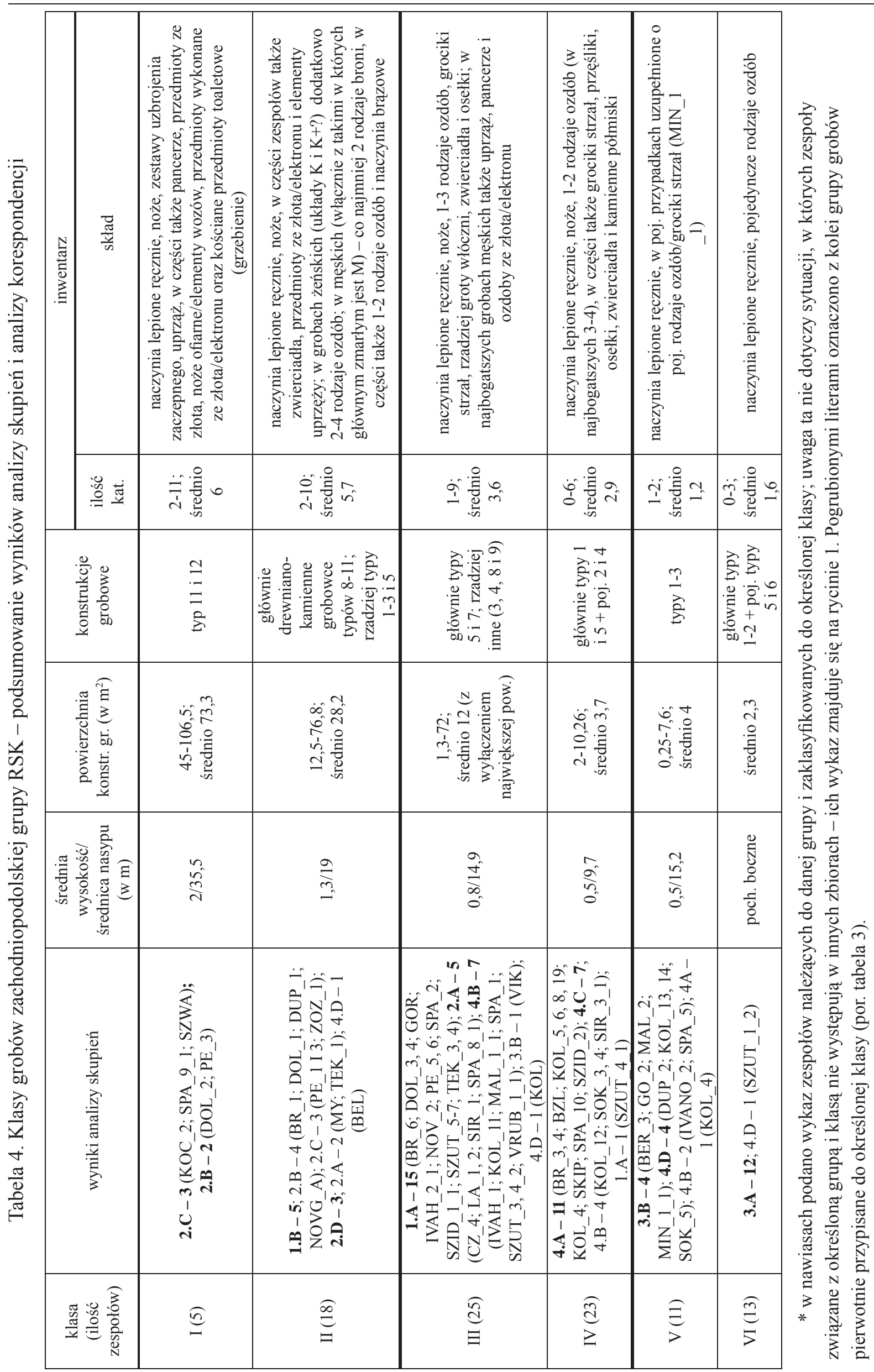




\section{ANEKS 1. WYKAZ ZESPOŁÓW GROBOWYCH ZACHODNIOPODOLSKIEJ GRUPY RSK WYKORZYSTANYCH W ANALIZACH}

Belousovka (BEL), obwód czerniowiecki, rejon sokiriański - kurhan nr 1 (Mogilov 2010, 120);

Berem'âny/B eremiany (BER), obwód tarnopolski, rejon buczacki - kurhan nr 3 (Sulimirski 1936, 64);

Bikìv/Byków (BIK), obwód lwowski, rejon drohobycki - kurhan nr 1 (Mahnik et al. 2003);

Bil'če Zolotoe/Bilcze Złote (BZL), obwód tarnopolski, rejon boroszczowski - kurhan nr 1 (Sulimirski 1936, 71);

Bratišiv/Bratyszów (BR), obwód iwanofrankiwski, rejon tłumacki - kurhany nr 1-6 (Sulimirski 1936, 45-62);

Čabanivka (CZ), obwód chmielnicki, rejon kamieniecki - kurhan nr 1, pochówek nr 2, kurhan nr 4 (Gucal et al. 2001, 18; Gucal et al. 2012, 143);

Dolinâny (DOL), obwód czerniowiecki, rejon chocimski - kurhany nr 1-4 (Smirnova 1969, 12; 1977);

D upliska (DUP), obwód tarnopolski, rejon zaleszczycki - kurhany 1-2 (Sulimirski 1936, 70-71);

Gorodok/G ródek nad D niestrem (GO), obwód tarnopolski, rejon zaleszczycki - kurhany 1-2 (Sulimirski 1936, 68-70);

Gorodnica/H orodnica (GOR), obwód iwanofrankiwski, rejon horodeński - kurhan nr 1 (Sulimirski 1936, 67);

I vahnivcì /I wachnowce(IVAH), obwód chmielnicki, rejon gródecki - kurhan nr 1 i 2 (pochówki nr 1-2) (Pułaski 1902, 6-20; Sulimirski 1936, 88-92);

I vanovce (IVANO), obwód czerniowiecki, rejon zastawieński - kurhan nr 1 (Mogilov 2010, 117120);

Kocûbinčinki/Kociubińczyki (KOC), obwód tarnopolski, rejon czortkowski - kurhan nr 2 (Bandrivskij 2009a; 2009b; 2013, 348-353);

Kolodiïvka (KOL), obwód chmielnicki, rejon kamieniecki - kurhany nr 1-8, 11-16, 19 (Gucal et al. 2005; 2006; 2007);

Kruglik (KRUG), obwód czerniowiecki, rejon chocimski - kurhan nr 1 (Smirnova 1969, 14-20);

Ladičin/Ladyczyn (LA), obwód tarnopolski, rejon trembowelski - kurhany nr 1 i 2 (Sulimirski 1936, 85-88);

Lenkìvì (LEN), obwód chmielnicki, rejon szepetowski - kurhan nr 1 (Melûkova 1953);
Malinìvcì (MAL), obwód chmielnicki, rejon kamieniecki - kurhany nr 1 (pochówki nr 1-4), 2-4 (Gucal et al. 2004, 114-116);

Min 'kìvci/Mińkowce (MIN), obwód chmielnicki, rejon dunajowiecki - kurhan nr 1, pochówki nr 1-2 (Bandrìvs'kij 2010b, 86);

M yškovce/M yszkowce (MY) (obecnie Celiïv), obwód tarnopolski, rejon husiatyński - kurhan nr 1 (Maleev 1991);

Novoselka (NOV), obwód czerniowiecki rejon zastawieński - kurhany nr 1 i 2 (Mogilov 2010, 117);

Novoselka-Grimajlovskaâ/Nowosiółka Grzymałowska (NOVG), obwód tarnopolski, rejon husiatyński - kurhan A (Sulimirski 1936, 81-82);

O selìvka (OSEL), obwód czerniowiecki, rejon kelmieniecki - kurhan nr 1 (Mogilov 2010, 115);

Perebykivci (PE), obwód czerniowiecki, rejon chocimski - kurhany nr 1-3, 5, 6 (Smirnova 1979);

Sirvatinci/Serwatyńce (SIR), obwód chmielnicki, rejon gródecki - kurhany nr 1 i 3 (pochówki nr 1-2) (Pułaski 1902, 20-36; Sulimirski 1936, 93-98);

Skipče/Skipcze (SKIP), obwód chmielnicki, rejon gródecki - kurhan nr 1 (Pułaski 1902, 36-39; Sulimirski 1936, 98);

Sokìlec (SOK), obwód chmielnicki, rejon dunajowiecki - kurhany nr 3-5 (Bandrìvs'kij and Zahar'ev 2002; Bandrìvs'kij 2010b, 88, 107-109);

Spasivka (SPA), obwód chmielnicki, rejon gródecki - kurhany nr 2, 3, 5, 8 (pochówki nr 1-3), 9 (pochówki nr 1 i 2) (Gucal et al. 2009, 91-93; Gucal et al. 2010, 101-103; Gucal 2012);

Šidlivci/Szydłowce (SZID), obwód tarnopolski, rejon husiatyński - kurhany nr 1 (pochówki nr 1-2) i 2 (Sulimirski 1936, 74-78);

Šutnivcì (SZUT), obwód czerniewicki, rejon kamieniecki - kurhany nr 1 (pochówki nr 1-2), 2, 3, 4 (pochówki nr 1-2), 5-7 (Gucal et al. 1998; 2001; Gucal, Gucal 2009a; 2009b);

Švajkìvci/Szwajkowce (SZWA), obwód tarnopolski, rejon czortkowski - kurhan nr 1 (Bandrìvskij 2009b; 2013, 342-348);

Teklìvka (TEK), obwód chmielnicki, rejon kamieniecki - kurhany nr 1-4 (Gucal et al. 2003; 2008; 2011a; 2011b); 
Vikno (VIK), obwód czerniowiecki, rejon zastawieński - kurhan nr 1 (Mogilov 2010, 117);

Vrublivci (VRUB), obwód chmielnicki, rejon kamieniecki - kurhan nr 1, pochówki nr 1 i 2 (Kučugura 1995);
Zozulinci/Zazulince (ZOZ), obwód tarnopolski, rejon zaleszczycki - kurhan nr 1 (Maleev 1992; 2007);

\section{ANEKS 2. CECHY OBRZĄDKU POGRZEBOWEGO ZACHODNIOPODOLSKIEJ GRUPY RSK UWZGLĘDNIONE PRZY ANALIZACH}

I. charakter pochówku i wielkość przykrywającego go nasypu ${ }^{17}$ :

1. pochówki centralne/główne (pochówki zajmujące centralną lokalizację w obrębie przestrzeni wyznaczonej przez nasyp kurhanowy), nakryte nasypami pierwszej grupy wielkościowej (nasypy o średnicy do $16 \mathrm{~m}$ i wysokości pomiędzy 0,1 a $2 \mathrm{~m}$ );

2. pochówki centralne nakryte nasypami drugiej grupy wielkościowej (nasypy o średnicy między 17 a $30 \mathrm{~m}$ przy wysokości rzędu 0,33,8 m);

3. pochówki centralne nakryte nasypami trzeciej grupy wielkościowej (nasypy o wysokości wynoszącej co najmniej $2 \mathrm{~m}$ i średnicy równej lub większej niż $40 \mathrm{~m}$ );

4. poboczne pochówki zlokalizowane poza centralną partią nasypu;

5. pochówki wpuszczone w starsze nasypy kurhanowe;

II. parametry budowli grobowej i jej cechy konstrukcyjne:

maksymalne powierzchnie konstrukcji grobowej:

6. powierzchnie pierwszej grupy wielkościowej (konstrukcje grobowe o powierzchniach wynoszących nie więcej niż $7,56 \mathrm{~m}^{2}$, przy czym ich szerokość jest nie większa niż 2,9 m);

7. powierzchnie drugiej grupy wielkościowej (konstrukcje grobowe o powierzchniach równych co najmniej $6,75 \mathrm{~m}^{2}$, ale nie większych niż $32 \mathrm{~m}^{2}$ );

17 Ilość grup wielkościowych i ich przedziały wyznaczone zostały za pomoca metod statystycznych - korelacji Pearsona i analizy skupień metodą k-średnich. Wielkość nasypu kurhanowego wyrażona jest poprzez jego wysokość i średnicę, natomiast powierzchnia konstrukcji grobowych - poprzez ich długość i szerokość.
8. powierzchnie trzeciej grupy wielkościowej (konstrukcje grobowe o powierzchniach wynoszacych co najmniej $33 \mathrm{~m}^{2}$ );

typy konstrukcji grobowych ${ }^{18}$ :

9. typ 1 - proste groby zakładane albo bezpośrednio na dawnej powierzchni gruntu albo umieszczane na specjalnie przygotowanym bruku kamiennym również znajdującym się na poziomie dawnej powierzchni podkurhanowej;

10. typ 2 - proste groby zakładane w prostych jamach bez konstrukcji dodatkowych;

11. typ 3 - groby w jamach z narożnymi dołkami bez śladów drewna, na ogół z kamiennym oblicowaniem ścian;

12. typ 4 - zakładane na dawnej powierzchni podkurhanowej proste konstrukcje grobowe ze ścianami oblicowanymi kamieniami (względnie kamienne skrzynki);

13. typ 5-zakładane na dawnej powierzchni podkurhanowej proste drewniane grobowce słu-

18 Na potrzeby zaprezentowanych w niniejszym artykule analiz stworzono nową klasyfikację konstrukcji grobowych zachodniopodolskiej grupy RSK. Przy jej tworzeniu wykorzystano kryteria podziału zaproponowane przez N. Eberts (2012, 326-328), dokonując jednocześnie pewnych ich modyfikacji. Kryteria te to lokalizacja konstrukcji grobowej w 1) obrębie jamy lub 2) na dawnej powierzchni podkurhanowej + obecność lub nieobecność takich elementów konstrukcyjnych jak 3) dołki posłupowe i 4) rowki ze śladami drewna, 5) słupy i rowki bez śladów drewna, 6) kamienne oblicowanie ścian i 7) dromos. Przy tworzeniu klasyfikacji posłużono się analizami statycznymi - hierarchiczną analizą skupień z wykorzystaniem metody aglomeracji Warda z wykorzystaniem odległości euklidesowej. W rezultacie otrzymano 12 różnych wariantów konstrukcji grobowych. 
powej formy (ich pozostałości stanowią dołki posłupowe ze śladami drewna);

14. typ 6 - groby w jamach z kamiennymi ścianami lub ścianami oblicowanymi kamieniami;

15. typ 7 - proste drewniane grobowce słupowe zakładane w jamach;

16. typ 8 - słupowe drewniano-kamienne grobowce ze ścianami oblicowanymi kamieniami zakładane na dawnej powierzchni podkurhanowej;

17. typ 9 - konstrukcje jak w typie 8, ale zakładane $\mathrm{w}$ jamach, a nie na dawnej powierzchni podkurhanowej;

18. typ 10 - zakładane $w$ jamach drewniane grobowce słupowe złożonej formy $\mathrm{z}$ rowkami i kamiennym oblicowaniem ścian;

19. typ 11 -złożone drewniano-kamienne grobowce słupowe z rowkami, kamiennym oblicowaniem ścian i dromosami zakładane na dawnej powierzchni podkurhanowej;

20. typ 12 - konstrukcje jak w typie 11, ale zakładane w jamach, a nie na dawnej powierzchni podkurhanowej;

obecność dodatkowych elementów konstrukcyjnych $\mathrm{w}$ postaci:

21. bruku kamiennego;

22. dookolnego kamiennego ogrodzenia/pierścienia/krepidy wokół konstrukcji grobowej;

III. Ilość i skład inwentarza - kategorie inwen$\operatorname{tarza}^{19}$ :

23. nóż;

24. osełka;

25. przęślik;
26. grociki strzał;

27. broń drzewcowa;

28. broń obuchowa;

29. broń sieczna (okucie pochwy);

30. uzbrojenie ochronne;

31. elementy rzędu końskiego;

32. zestawy paciorków;

33. pojedyncze paciorki;

34. bransolety metalowe;

35. zawieszki, wisiorki, amulety itp.;

36. zausznice;

37. szpile;

38. ozdoby - pozostałe;

39. przedmioty wykonane ze złota lub elektronu;

40. naczynia lepione ręcznie;

41. naczynia toczone na kole;

42. naczynia brązowe lub drewniane z brązowymi nakładkami (?);

43. kamienny półmisek/płytka;

44. siarka, realgar, barwniki;

45. brązowe zwierciadła;

46. przedmioty toaletowe z kości i poroża (piksyda, łyżeczki kosmetyczne z półmiskami z poroża, grzebienie);

47. przedmioty związane z działaniami ceremonialnymi i kultowymi (brązowe noże ofiarne i zwieńczenia tyczek, elementy wozów);

48. pokarm ofiarny.

19 W wykazie cech uwzględniono tylko te kategorie przedmiotów inwentarza, które wystąpiły w co najmniej trzech zespołach grobowych.

\section{BIBLIOGRAFIA}

\section{Antyczne źródła pisane:}

Herodot, D zieje, Z języka greckiego przełożył i opracował Seweryn Hammer, Warszawa 1959.

Lukian, Toksaris albo O przyjaźni. Dialogi 3. Przełożył i komentarzem opatrzył Władysław Madyda. Wrocław 1966.

\section{Literatura:}

Babenko L.I. 2005. Pesočinskij kurgannyj mogil’nik skifskogo vremeni. Har'kov.
Bandrivskij M.S. 2009. Kocûbinčiki-2 - novij pamâtnik epohi skifskoj archaiki na Srednem Pridnestrov'e (predwaritel'noe soobščenie). Bosporskij fenomen 2009, 30-38.

Bandrivskij M.S. 2013. Kurgany v Švajkovcah i Kocûbičkah - novyj istočnik dlâ datirovki Zapadno-podol'skoj grupy ranneskifskoj kultury (po materialam raskopok 2007-2009 gg.). Rossijskij arheologičeskij ežegodnik 3, 341-361.

Bandrìvs'kij M.S. 2009a. Elementi ceremonìal'noï kolìsnicì VII st. do nar. Hr. na Ternopil'ŝinì. Materiali ì doslidžennâ z arheologì̀ Prikarpattâ ì Volinì 13, 215-233. 
Bandrìvs'kij M. 2009b. Novij ritual'nij ob'ekt časìv skìfs'koï archaiki zì Švajkìvec' bìlâ Čortkova na Ternopil'ŝinì (poperedne povìdomlennâ). (W:) V.V. Otroŝenko et al. (red.), Vzaemozv'âzki kul'tur epoh bronzi ì rann'ogo zaliza na teritorï Central'noï Evropi. Zbirka naukovih prac' na pošanu Larisi İvanìni Krušel'nic'koï. Kiïv-L'vìv, 202-220.

Bandrìvs'kij M. 2009c. Svâtiliŝe Aresa v Kocûbinčikah za Zahìdnomu Podillì v kontekstì egejs'kih vplivìv na panteon carstva Skolotìv. Materiali i doslidžennâ z arheologiï Prikarpattâ ì Volinì 13, 113-126.

Bandrìvs'kij M. 2010a. Obrazotvorčì tradiciï na zahodì Ukraïns'kogo Lìsostepu v VII - napočatku VI st. do nar. Hr.: vitoki ì pričini transformaciï. Arheologičeskij al'manah 21, 145-177.

Bandrìvs'kij M.S. 2010b. Pam'âtki seredn'odnìstrovs'koï (zahìdnopodìl'skoï) grupi rann'ozalìznogo vìku v central'noevropejs'kìj hronologìcnìj škalì ta problem perìodizaciï. Materiali ì doslìdžennâ $z$ arheologï Prikarpattâ ì Volinì 14, 76-113.

Bandrìvs'kij M. 2014. Kul'turno-ìstoričnì procesi na Prikarpattì ì Zahìdnomu Podillì v pìznìj period epohi bronzi - na počatku dobi rann'ogo zalìza. L'vìv.

Bandrìvs'kij M., Zhar'ev V. 2002. Pro odin tip pohoval'nih sporud perìodu rann'ogo zalìza na Sredn'omu Pridnìstrov’î (Za materìalami raskopok kurganu III v selì Sokìlec' v 1999 roci). Zapiski Naukovogo tovaristva imeni Ševčenka 244, 545-562.

Bessonova S.S. 1992. Žertvoprinošeniâ podrostkov v skifskih kurganach. (W:) B.N. Mozolevskij (ed.), Kimmerijcy i skify: tezisy II Meždunarodnoj konferencji posvâsennoj pamâti A. I. Terenožkina. Melitopol', 11-12.

Bessonova S.S. 1998. Družinnye kurgany v ukrainskoj lesostepi skifskogo vremeni. (W:) L.E. Nemčinova and T.M. Tallerčik (red.), Skify, H azary, Slavâne, D revnââ Rus'. K 100-letîu so dlâ roždeniâ M.I. Artamanova. Sankt-Peterburg, 57-58.

Brémond A., Couet J.F., Davie A. 2006. Kompendium wiedzy o socjologii. Przekład K. Malaga. Warszawa.

Błaszczyk D. 2013. Changing archaeological paradigms and the interpretation of cemeteries. Analecta Archaeologica Ressoviensia 8, 341-360.

Bojko U.N. 1986. Social'nyj sostan nasseleniâ bassejna r. Vorskly v skifskoe vremâ (VII-III vv. do n.e.). Har'kov.

Bojko Û.N. 1987. Otraženie social'noj struktury v ideologii i kul'tovoj praktike naseleniâ Vorsklinskogo regiona skifskogo vremeni. (W:) D.A. Krajnov (red.), Religioznye predstavleniâ v pervobytnom obŝestve. Moskva, 176-179.
Bojko Û.N. 1991. Iz opyta modelirovaniâ social'nogo razvitiâ zemledel'cev Vostočnoj Evropy. (W:) E.V. Ârovoj (red.), Drevneišie obŝnosti zemledel'cev i skotovodov severnogo Pričernomor'â ( $V$ tys. do n.e.-V vek n.e.). Kiev, 164-166.

Bojko Û.N. 1994. Sociologiâ vostočnoevropejskogo goroda I tys. do n.e. (po materialam Belousovkas'kogo gorodiŝa i Vorsklinskoj regional'noj sistemy skifskogo vremeni). Drevnosti 1, 29-42.

Boltrik Û.V. 2004. Social'naâ struktura Skifii IV v. do R.H., otražennaâ v pogrebal'nyh pamâtnikah. (W:) J. Chochorowski (red.), Kimmerowie, Scytowie, Sarmaci: księga poświęcona pamięci profesora Tadeusza Sulimirskiego. Kraków, 85-91.

Brown J. 1995. On Mortuary Analysis - with Special Reference to the Saxe-Binford Research Program. (W:) L.A. Beck (red.), Regional Approaches to Mortuary Analysis. New York, London, 3-26.

Bujnov Û.V., Okatenko V.N. 2013. K voprosu o social'noj strukture naseleniâ severskodoneckoj Lesostepi V-IV vv. do n.e. Drevnosti 12, 123-136.

Bunâtân E.P. 1985. Metodika socail'nyh rekonstrukcij v arheologii na material skifskih mogil'nikov IV-III vv. do n.e. Kiev.

Burghardt M. 2015. Weapon and the military of the population of the West Podolian group of the Early Scythian culture in the light of sepulchral sources. Materiaty i Sprawozdania Rzeszowskiego Ośrodka Archeologicznego 36,143-166.

Chapman R. 2003. Death, society and archaeology: the social dimensions of mortuary practices. M ortality 8 (3), 305-312.

Chochorowski J. 2015. Scytowie a Europa Środkowa - historyczna interpretacja archeologicznej rzeczywistości. Materiały i Sprawozdania Rzeszowskiego Ośrodka Archeologicznego 35, 9-58.

Ciesielska A. 2002. Elementy teorii spolecznej $w$ archeologii. Koncepcje grup, instytucji i struktur społecznych. Poznań.

Ciesielska A. 2009. Cmentarzyska jako źródła do badania struktury społecznej. (W:) W. Dzieduszycki, J. Wrzesiński (red.), Metody. Źródła. Interpretacje. Funeralia Lednickie 11, 43-47.

Dwight W.R. 1989. Statistical Methods and Reasoning in Archaeological Research: A Review of Praxis and Promise. J ournal of Q uantitative Anthropology 1, 5-78.

Eberts N. 2012. Problema interpretacii pogrebal'nyh obrâdov Zapadno-Podol'skoj gruppy ranneskifskoj kul'tury. (W:) V.A. Alekšin et al. (red.), Kul'tury stepnoj Evrazii i in vzaimodejstvie s drevnimi civilizaciâmi 2. Sankt-Peterburg, 325-332. 
Fleming A. 1973. Tombs for the Living. Man 8 (2), 177193.

Galanina L.K. 1994. O kriteriâh vydeleniâ „,carskih” kurganov ranneskifskoj epohi. (W:) A.Û. Alekseev et al. (red.), Elitnye kurgany stepej Evrazii v skifosarmatskuû epohu. Sankt-Peterburg, 76-81.

Gavriljuk N.A. 2003. The Graeco-Scythian Slave-trade in the $6^{\text {th }}$ and $5^{\text {th }}$ Centuries BC. Black Sea Studies 1, $75-85$.

Gawlik A. 2009. Scythian influences on the western and north-western borderlands of Great Scythia. Recherches Archéologiques SN 1, $605-612$.

Gawlik A. 2010. Interpretation of cultural transformations in the Early Iron Age in South-Eastern Poland and Western Ukraine. (W:) K. Dzięgielewski et al. (red.), Migration in Bronze and Early Iron Age. Prace Archeologiczne 63. Kraków, 153-172.

Gryzińska-Sawicka N. 2014. Obraz struktury społecznej ludności kultury wielbarskiej w świetle źródeł archeologicznych i danych antropologicznych. (W:) W. Dzieduszycki, J. Wrzesiński (red.), Królowie i biskupi, rycerze i chłopi-identyfikacja zmartych. Funeralia Lednickie 16, 51-61.

Gucal A.F. 2004. Skìfs'kì kindžali z Podillâ. Naukovì pracì Kam'ânec'-podil's'kogo Deržavnogo Universitetu. İstoričnì nauki 12, 43-47.

Gucal A.F. 2012. Roboti na pam'âtkah arheologii v rajonì Satanivs'kih Tovtr. Naykovì pracì Kam'ânec' Podil's'kogo nacional'nogo unìversitetu ìmena 0 gìenka 21, 147-156.

Gucal A.F., Gucal V.A. 2009a. Kurganna grupa rann'oskìfs'kogo času u ponizzì Smotriča. Vìsnik Kam'ânec'-Podil'skogo nacional'nogo unìversitetu ìm. İvana 0 gìenka 2, 5-15.

Gucal A.F., Gucal V.A. 2009b. Kurgannij kompleks z bronzovim dzerkalom ìz Šutnovec'. (W:) S.S. Bessonova (red.), Epoha rannego železa. Sbornik naučnyh trudov k 60-letiû S.A. Skorego. Kiev-Poltava, 125-134.

Gucal A.F., Gucal V.A., Megej V.P. 1998. Doslìdžennâ kurganìv skìfs'kogo času na Seredn'omu Podnìstrov'ï. Arheologičnì vidkrittâ v Ukraïni 1997-1998 rr. Kiïv, 74-75.

Gucal A.F., Gucal V.A. Megej V.P. 2001. Rozkopki kurganìv skìfs'kogo času na Kam'âneččinì. Arheologǐnni vidkrittâ v Ukraïnì 1999-2000 rr. Kï̈v, 17-18.

Gucal A.F., Gucal V.A., Megej V.P., Mogilov O.D. 2003. Rezul'tati doslìdžen' kurganìv skìfs'kogo času bìlâ s. Teklìvka na Podillì. Arheologičnì vidkrittâ v Ukraïni 2001-2001 rr. Kiïv, 90-92.

Gucal A.F., Gucal V.A., Megej V.P., Mogilov O.D. 2004. Roskopki kurganìv epohi rann'ogo zalìza v s. Malinìvcì na Seredn'omu Dnìstrì. Arheologični vidkrittâ v Ukraïni 2002-2003 rr. Kï̈v, 114-116.

Gucal A.F., Gucal V.A., Megej V.P., Mogilov O.D. 2005. Kurgani rann'oskìfs'koï dobi bìlâ sela Kolodïvka na Seredn'omu Dnìstrì. Arheologični doslidžennâ v Ukraïni 2003-2004 rr. Zaporìžžâ, 118-119.

Gucal A.F., Gucal V.A., Megej V.P., Mogilov O.D. 2006. Rozkopki kurganìv rann'oskìfs'koï dobi bìlâ sela Kolodiïvka u Seredn'omu Podnìstrov'i. Arheologični doslidžennâ v Ukraïni 2004-2005 rr. Kiïv, 157-159.

Gucal A.F., Gucal V.A., Megej V.P., Mogilov O.D. 2012. Teklìvs'kij kurgannij nekropol'. Vìsnik Kam'ânec' Podil'skogo nacional'nogo unìversitetu ìm. İvana 0 gìenka 1, 6-23.

Gucal A.F., Gucal V.A., Megej V.P., Mogilov O.D., Boltanûk P.A. 2007. Prodovžennâ robìt na kurganah rann'oskìfs' kogo času bìlâ s. Kolodï̀vka. Arheologičnì doslidžennâ v Ukraïni 2005-2007 rr. Kiïv, 158-160.

Gucal A.F., Gucal V.A., Megej V.P., Mogilov O.D., Baženov O.L., Boltanûk P.A. 2009. Doslìdžennâ kurganìv rann'oskìfs'kogo času v rajonì serebn'oï tečiï r Zbruč. Arheologični doslidžennâ v Ukraïnì 20062007 rr. Kiïv, 91-93.

Gucal A.F., Gucal V.A., Mogilov O.D., Boltanûk P.A. 2010. Doslìdžennâ kurgannoï grupi Spasìvka-Ìvankìvcì u Pozbruččì. Arheologičnì doslidžennâ v Ukraïnì 2009 r.. Kïv-Luc'k, 101-103.

Gucal A.F., Gucal V.A., Mogilov A.D. 2011a. Kurgan nr 3 u s. Teklivka na Srednem Dnestre. (W:) V.D. Berezuckij et al. (red.), Vostočnoevropejske drevnosti skifskoj epohi. Voronež, 97-109.

Gucal A.F., Gucal V.A., Mogilov A.D. 2011b. Teklìvs'kì kurganu na Zahìdnomu Podillì. (W:) S.I. Posohov (red.), Drevnosti Vostočnoj Evropy. Sbornik naučnih trudov k 90-letiû B.A. Šramko. Har'kov, 111-124.

Gucal A.F., Gucal V.A., Mogilov A.D. 2012. Novye issledovaniâ kurganov skifskogo vremeni na zapade vostočnoevropejskoj lesostepi. (W:) B.A. Bajtanaev et al. (red.), Materialy III meždunarodnoj naučnoj konferencii ,Kadyrbaeskie četeniâ 2012. Aktobe, 141-154.

Härke H. 1997. The nature of burial data. (W:) C.K. Jensen and K.H. Nielsen (red.). Burial and society: the chronological and social analysis of archaeological burial data. Aarhus, 19-27.

Härke H. 2000. Social Analysis of Mortuary Evidence in German Protohistoric Archaeology. Journal of Anthropological Archaeology 19. 369-384.

Hedeager L. 1978. Process towards state formation in Early Iron Age Denmark. (W:) K. Kristiansen, C. Paludan-Müller (red.), New Directions in Scandinavian Archaeology. Copenhagen, 217-223. 
Hedeager L. 1992. Iron-Age Societies. From Tribe to State in Northern Europe 500 BC to AD 700. Oxford.

Hodson F.R. 1977. Quantifying Hallstatt: some initial results. American Antiquity 42, 406-410.

Il'inskaâ V.A. 1966. Skifskie kurgany okolo Borispolâ. Sovetskaâ Arheologiâ 3, 152-172.

Ivantchik A. 2011. The Funeral of Scythian Kings: The historical reality and the description of Herodotus (IV, 71-72). (W:) L. Bonfante (red.), European Barbarians. Cambridge, 71-106.

Kovpanenko G.T., Bessonova S.S., Skoryj S.A. 1989. Pamâtniki skifskoj epohi D neprovskogo L esostepnogo Pravoberež’â (Kievo-Čerkasskij region). Kiev.

Kučugura L.Ì. 1995. Rann'oskìfs'kij kompleks z kurhanu poblizu s. Vrublìvcì v Podnìstrov’ï. Arheologiâ 1995 (2), 131-135.

Kubczak J. 1978. Kurhany arystokracji scytyjskiej. Poznań.

Lewartowski K. 2001. Archeologia śmierci - stan i potencjał. Światowit. Nowa seria 3 (44). 133-143.

Mahnì J., Pavlìv D., Petegirič V. 2003. Kurganne pohovannâ rann'oskits'kogo času u verhìv'âh Dnìstra. (W:) J. Gancarski (red.), Epoka brqzu i wczesna epoka żelaza w Karpatach polskich. Krosno, 531-548.

Maleev Û.M. 1991. Kurgan skifskogo vremeni u s. Myškovcy v basejne r. Zbruč. (W:) Û.V. Boltrik, E.P. Bunâtân (red.) Kurgany Stepnoj Skifii. Kiev, 122-131.

Maleev Û.M. 1992. Novij kurgan skifskogo vremeni v Zapadnoj Podolii. (W:) B.N. Mozolevskij (red.), Kimmerijcy i skify: tezisy II Meždunarodnoj konferencji posvâsennoj pamâti A. I. Terenožkina, Melitopol', 53-54.

Maleev Û.M. 2007. Zozulincì - kurgan rann'oskìfs'kogo času na Dnìstrì. Zapiski Naukovogo tovaristva imeni Ševčenka 253, 634-649.

Medvedskaâ I.N. 1992. Periodizaciâ skifskoj arhaiki i Drevnij Vostok. Sovetskaâ Arheologiâ 1992 (3), 86107.

Melûkova A.I. 1953. Pamâtniki skifskogo vremeni na Serednem Dnestre. Kratkie soobŝeniâ Instituta istorii material'noj kultury 51, 60-73.

Mizoguchi K. 1993. Time in the Reproduction of Morutary Practices. World Archaeology 25 (2), 223-235.

Mogilov A. 2010. K arheologičeskoj karte Severnoj Bukoviny rannego železnogo veka. Revista Arheologică. serie nouă V (1), 98-129.

Moruženko A.A. 1991. Social'naâ struktura lesostepnogo naseleniâ meždureč'â Dnepra i Dona v skifskoe vremâ. (W:) E. V. Ârovoj (red.), Drevneišie obŝnosti zemledel'cev i skotovodov severnogo Pričernomor'â (V tys. do n.e.-V vek n.e.). Kiev, 163-164.
O’Shea J. 1984. Mortuary Variability: An Archaeological Investigation. New York.

Peebles Ch.S., Kus S.M. 1977. Some Archaeological Correlates of Ranked Societies. American Antiquity 42 (3), 421-448.

Petrenko V.G. 2006. Krasnoznamenskij mogil'nik. Elitnye kurgany ranneskifskoj epohi na Severnom Kavkaze. Steppenvölker Eurasiensis 3. Berlin, Bordo, Moskva.

Przybyła M.S. 2014. Społeczne hierarchie i archeologiczne rankingi grobów. Dyskusja w oparciu o analizy dwóch cmentarzysk z końca epoki brązu w Polsce południowej. (W:) T. Kurasiński, K. Skóra (red.) Grób w przestrzeni, przestrzeń $w$ grobie. Przestrzenne uwarunkowania $w$ dawnej obrzędowości pogrzebowej. Acta Archeologica Lodziensia 60, 7-28.

Pułaski F. 1902. Mogiły o nasypie kamiennym w powiecie Kamienieckim. Światowit 4, 1-39.

Renfrew C., Bahn P. 2002. Archeologia. Teorie, metody, praktyka. Warszawa.

Rolle R. 1979. Totenkult der Skythen: Das Steppengebiet. Vorgeschichtliche Forschungen 18/1. Berlin, New York.

Romaško V.A., Skoryj S.A. 2009. Bliznec-2. Skifskij aristokratičeskij kurgan v Dneprovskom Pravoberežnom Nadporož'e. Dnìpropetrovs'k.

Samokvasov D.Â. 1908. Mogily Russkoj Zemli. Moskva.

Skoryj S.A. 1990. Kurgan Perepâtiha (do etnokul'turnoï istorï Dnìprovs'kogo Lisostepovego Pravoberežžâ). Kiev.

Smirnova G.I. 1967. Nekotorye voprosy ranneskifskšogo perioda na Srednem Dnestre (Po powodu stat'i M. Dušeka). Archeologické Rozhledy 19 (2), 223-235.

Smirnova G.I. 1969. Raskopki kurganov u sel Kruglik i Dolinâny na Bukovine. Arheologičeskij Sbornik 10, 14-27.

Smirnova G.I. 1977. Kurgannyj mogil’nik ranneskifskogo vremeni u sela Dolinâny. Arheologičeskij Sbornik 18, 32-40.

Smirnova G.I. 1979. Kurgany u sela Perebykovcy - novyj mogil'nik skifskoj archaiki na Sredem Dnestre. Arheologičeskij Sbornik 20, 37-67.

Smirnova G.I. 1998. Die Ostkarpatenregion zur Vorskythen - und Skythenzeit und die osteuropäischen Steppen: kontakte und Migrationen. (W:) B. Hänsel, J. Machnik (red.), Das Karpatenbecken und die Osteuropäisheche Steppe. München - Radhen/Westf., 451-465.

Smirnova G.I. 2004. Sostoânie izučeniâ ZapadnoPodol'skoj grupy pamâtnikov ranneskifskogo vremeni v Lesostepnoj Skifii v konce XX veka. (W:) J. Chochorowski (red.), Kimmerowie, Scytowie, Sarmaci: 
księga pamiatkowa poświęcona pamięci profesora Tadeusza Sulimirskiego. Kraków, 409-429.

Šul'ženko M.A. 1987a. K voprosy o social'noj interpretacji pogrebalnogo obrada ranneskifskih kurganov Posul'â. Istoričeskie čteniâ pamâti Mihaila Petroviča Grâznova. Omsk, 143-145.

Šul'ženko M.A. 1987b. O sociologičeskoj klassifikacii ranneskifskih pogrebenij Posul'â. (W:) A.A. Tiškin (red.), Aktyal'nye problemy istoriko-arheologičeskih issledovanij. Kiev, 179-180.

Vasûtin S.A., Kardin N.N., Tiškin A.A. 2005. Rekonstrukcii social'noj struktury rannih kočevnikov v arheologii. (W:) N.N. Kardin et al. (red.) Social' naâ struktura rannih kočovnikov Evrazii. Irkutsk, 16-44.

Tainter J. 1975. Social inference and mortuary practices: an experiment in numerical classification. World Archaeology $7,1-15$
Tainter J. 1978. Mortuary practices and the study of prehistoric social systems. Advances in Archaeological Method and Theory 1, 105-141.

Zimmermann A. 1997. Zur Anwendung der Korrespondenzanalyse in der Archäologia. (W:) J. Müller, A. Zimmermann (eds.), Archäologie und Korrespondenzanalyse. Beispiele, Fragen, Perspektiven. Internationale Archäologie 23, 9-15.

Strony internetowe:

Baxter M.J. 2015. Notes on Quantitative Archaeology and R. https://nottinghamtrent.academia.edu/MikeBax ter (dostęp 10 lutego 2016 r.).

Madsen T. 2007. Multivariate data analysis with PCA, CA and MS. www.archaeoinfo.dk/PDF\%20files/Multivaria te\%20data\%20analysis.pdf (dostęp 25 lutego 2016 r.).

http://www.lvivpost.net/lvivnews/n/8508 (dostęp 20 grudnia 2015 r.).

\title{
SOCIAL STRATIFICATION OF THE POPULATION OF THE WESTERN-PODOLIAN GROUP OF THE EARLY SCYTHIAN CULTURE
}

\author{
SUMMARY
}

\section{Introductory issues}

The aim of the paper is to present one of the possible ways to study and interpret the importance of the funeral rites for the reconstruction of social stratification of the Western-Podolian group of the Early Scythian culture (ESC). Up to the present, any detailed studies have not been conducted in this area for this group. This issue was raised only in a general way, usually by drawing attention to the presence of the graves in the Western-Podolian group of the ESC, which can be combined with the higher classes (the aristocracy) (Smirnova 1979, 41; Gawlik 2010, 162; Gucal et al. 2011a, 106; Gucal 2012, 154). This question was also raised in connection with the research on the genesis of this groups, for it has been assumed that the representatives of the "western-Podolian" elites came from a nomadic ("Scythian") environment (Sulimirski 1936, 29; Smirnova 1998, 460; Gawlik 2010, 156-157, 160-162; Chochorowski 2015, 25).

\section{The selection of characteristics of the funeral rite for analyses and source criticism}

The first stage of the research was to determine the characteristics of the funeral rite used by the population of the Western-Podolian group of the ESC, useful for social analysis. Detailed analysis of the elements of the funeral rite, widely considered as useful in the research on social differentiation of ancient human groups, showed that the way in which the body was buried is the most promising for the research on the issues undertaken in this paper. The starting point for research on this aspect of the funeral rite of the analyzed population was the conception of effort (energy loss) used by the mourners to erect the burial structure and to organize the burial ceremony (Tainter 1975, 1978). According to its assumptions, the higher social position of the deceased, the higher energy loss was used for his funeral. In the case of the Scythian communities (of the "Scythian" cultural model), Herodotus confirms the accuracy of this conception for the study of social differentiation (IV, 71). In the course of analysis of the funeral sources of the Western-Podolian group of the ESC, it was established that in its case the amount of work used for the organization of a funeral ceremony is reflected in the size of a grave and degree of its complexity. In the course of further analysis of the funeral rite of the studied community, it has been established that richness of grave goods is also no less important criterion for determination of social position of the deceased. At the same time, it was indicated that important for the research is not the total number of artefacts in the 
grave, but the presence (or absence) of certain categories of functional objects.

Based on the analysis of the above-mentioned aspects of the funeral rite of the Western-Podolian group of the ESC, 48 characteristics of the rite have been separated. The list of the characteristics, along with a discussion on the basis of the distinguishing of some of the variables (size characteristics and diversity of burial constructions), is in the end of the publication (Appendix No. 2).

\section{The classification of burials of the Western-Podolian group of the ESC}

\subsection{The cluster analysis}

An attempt to notice groups of burials, which can be connected with various social groups, is the main task of this part of the paper. For this purpose, the classification of 100 selected burial complexes of the examined group has been made (Appendix No. 1). The appropriate systematization of graves was carried out using cluster analysis and the Ward's method. Its results are shown in Figure 1. The detailed analysis of the complexes, grouped using the Ward's method, enabled to identify the most similar to each other in terms of the studied characteristics of the funeral rite. Two intersections have been made. The first has been made at the 8 th bond distance, and four main clusters have been distinguished on this basis. Further analysis of the complexes grouped within separate clusters revealed the existence of smaller sets (subclusters) within them. They differ from each other, except in quantity characteristics, also in the composition of the grave goods, and to a lesser extent, in the complexity of the burial structures. The analysis, carried out in this respect, showed that the optimal intersection of the dendrogram is in about 4 and $2 / 3$ of the bond distance - 12 group of graves has been distinguished on this basis. Their characteristics are presented in Table 1.

The analysis of the data from the presented table leads to two important observations. Firstly, the distinguished groups of graves exhibit certain characteristics allowing their identification with the burial places of people belonging to different social groups. Consequently, it can be assumed that the examined society was characterized by complex social structure. Secondly, far-reaching similarities are visible between a part of the separate sets (groups) of graves, and the most similar groups do not always have to be grouped under one of the four major clusters. This observation leads to the conclusion that the most similar groups of graves can be combined into larger sets - classes.

\subsection{Comparative analysis of the separate groups of graves}

The next stage of the research was to conduct a comparative analysis of the groups of burials distinguished above for their systematization. The starting point for this part of the analysis is the definition of the social stratification, indicating in sociology the arrangement of a society in a hierarchy according to the social position, from the highest to the lowest (Brémond et al. 2006, p. 167). No less important for the comparative analysis of the groups of graves distinguished by the cluster analysis is the statement of the mutual similarity among some of these graves and the possibility of combining them into larger sets (classes).

The total number of 12 groups of graves, distinguished by the cluster analysis, have been reduced to six sets (classes), on the basis of the comparative analysis carried out in terms of such factors as: a place in the consecutive rankings reflecting the amount of work dedicated to the construction of a grave (the rankings: "the height of burial mounds", "the diameter of burial mounds" and "the surface of burial constructions" - fig. 2-4), the "richness" of grave goods (the rankings: "the NAT points" and "the splendour coefficient" - fig. 5 and 6) and the presence or absence of the separate types of burial constructions and certain groups of artefacts or their sets (fig. 7). The classes of graves distinguished by this method have been then arranged according to the above presented definition of the social stratification (hierarchy), that is in such a way that the transition to the subsequent classes (from I to VI) is connected with the decreased amount of work used to built the burial construction and the burial mound, and the grave goods are getting "poorer" (less varied qualitatively and quantitatively). The characteristics of each class of graves, along with the basics of their distinguishing, are presented in Table 3.

\subsection{The correspondence analysis}

The verification of the graves classification, created on the basis of the cluster analysis, has been the final stage of the analysis of the social differentiation of the population of the Western-Podolian group of the ESC in the light of funeral sources. The correspondence analysis has been used for this purpose. The results are shown in Figure No. 8 . The analysis of the correspondence table leads to two basic observations. Firstly, the results of the correspondence analysis are basically consistent with the results of earlier studies - both 12 groups defined by the cluster analysis, and the six classes of graves distinguished in the course of further classification of these groups, create, at least partially, separate clusters. Only in a few cases, the complexes associated with a given group/class of graves are outside their main clusters (mainly groups 1.A and 4.B). The modi- 
fied division of graves of the Western-Podolian group of the ESC into classes, taking into account the remarks made during the analysis of the correspondence table, are shown in Table 4.

The observation of a parabolic distribution of the examined characteristics of the funeral rite on the correspondence table and the burial complexes described by them is no less important for the verification of the classification of the graves of the Western-Podolian group of the ESC, created on the basis of the cluster analysis. Such configuration of the data indicates the hierarchization of the distinguished classes of graves.

\section{The social structure of the population of the Western-Podolian group - the discussion}

In the early part of this chapter, the most important hypotheses about social differentiation of the Scythians and other groups of similar culture have been briefly presented. These theses, regardless of the sources on which their construction was based (either treated separately or confronted with each other the written sources (mainly The Histories by Herodotus) and the archaeological sources (graves), come down mainly to the pronouncement of the heterogeneity of these communities. The main indication of the heterogeneity is the existence of different social groups forming two or three main classes within these communities the aristocracy (including the royal elites, which sometimes are distinguished as a separate social class), the middle classes (the ordinary population) and the lower classes (the poor people and the dependent people with limited rights). A similar division has been also used for the population of the Western-Podolian group of the ESC.

The higher classes in the type of military aristocracy took the highest place in the social hierarchy of the population of the Western-Podolian group of the ESC. It was established that the members of this social class were buried in the graves of the I and the II classes (Table 4). Differences between the complexes grouped within these classes have shown that this class was not homogeneous and split up into two smaller social groups - the military elite of the highest level in the type of military leaders and chieftains (nomarchs by Herodotus?) and the "equestrian" aristocracy taking a lower position. Representatives of the first group were buried in the graves of the I class, members of the second - in the graves of the II class and in a few graves of the III class. In total, at least 27 graves connected with the elites of the examined population have been distinguished (33, including the complexes that have not been analysed).

People buried in the graves of the III and the IV classes took the middle place in the social hierarchy of the exam- ined population (Table 4). In the course of the analyses, it was established that the funeral complexes connected with them were burials of members of the middle class (the ordinary population). This class was the largest part of the examined population (in total, at least 49 complexes connected with this class have been distinguished +14 complexes with similar characteristics of the funeral rite), and, as in the case of the higher classes, it was not homogeneous. People buried in the graves of the III class took the higher place in the hierarchy of this class - the complexes of this class could be burials of the rich and distinguished members of the middle class. The presence of military items among their grave goods indicates that they were warriors. Other representatives of the ordinary population with lower social status were buried in the graves of the IV class. Agriculture, cattle breeding, crafts and perhaps trade were probably their main occupation.

Graves of the V class took the next to last place in the classification of graves of the Western-Podolian group of the ESC. Low amount of work used for the construction of the grave and the burial mound and poor grave goods indicate that people buried in the complexes of this class took one of the lowest places in the social hierarchy of the examined community - that were certainly the graves of the poorest people. In total, 10 such graves have been distinguished $(+2$ similar graves not included in the analyses).

Burials of the VI secondary class took the lowest place in the classification of funeral complexes of the examined population. Such characteristics of these complexes as: the location on the margins of burial mounds, small size, simplicity of the burial construction and poor grave goods indicate that the graves of this class belonged to people of a lower social position than the people, for whom specific burial mounds were built. In the light of this observation, it can be assumed that people buried in the graves of this class were (partially or totally) dependent on the people buried in the graves of the central location. Apart from the complexes of the VI class, dependent people could also be buried in shared graves with representatives of the local higher classes.

\section{Conclusions}

The research carried out in this paper has allowed to make the following comments on the social stratification of the population of the Western-Podolian group of the ESC:

It is justified to treat the funeral rite as a source for the recognition of the social stratification in the case of the studied community. Determining the amount of work used for preparing the burial (reflected by the size and complexity of 
the grave) and the richness of accompanying grave goods (especially the number of categories of artefacts) are the most important criteria for assessment of the social position of the deceased; the amount of work used for the organization of a funeral ceremony is reflected in the size of a grave and degree of its complexity.

The differentiation of the funeral complexes parallel to their grouping in some larger sets (groups and classes of graves) reflects the complexity of the social structure of the population of the Western-Podolian group of the ESC It consisted of several social groups forming three main social classes. The consecutive separated social classes are: the upper class (the elite) in the type of military aristocracy (military leaders, chieftains and the "equestrian" aristocracy); the middle class (ordinary population - privileged warriors (and women of similar social status) and the rest of the ordinary population of lower rank); the lower class (the poorest people and the people with limited rights).

Adres Autora:

\author{
Mgr Marcin Burghardt \\ Instytut Archeologii UR \\ ul. Moniuszki 10 \\ 35-015 Rzeszów \\ e-mail: marbur21@op.pl
}

